\title{
Trace Elements and Minerals in Fumarolic Sulfur: The Case of Ebeko Volcano, Kuriles
}

\author{
E. P. Shevko, ${ }^{1}$ S. B. Bortnikova, ${ }^{2}$ N. A. Abrosimova, ${ }^{2}$ V. S. Kamenetsky $\left(\mathbb{D},{ }^{3,4}\right.$ \\ S. P. Bortnikova, ${ }^{2}$ G. L. Panin, ${ }^{2}$ and M. Zelenski $\mathbb{i D}^{3}$ \\ ${ }^{1}$ Sobolev Institute of Geology and Mineralogy, SBRAS, Novosibirsk 630090, Russia \\ ${ }^{2}$ Trofimuk Institute of Petroleum Geology and Geophysics, SBRAS, No. 3, Novosibirsk 630090, Russia \\ ${ }^{3}$ Institute of Experimental Mineralogy RAS, Chernogolovka 142432, Russia \\ ${ }^{4}$ Earth Sciences and CODES, University of Tasmania, Private Bag 79, Hobart, TAS 7001, Australia
}

Correspondence should be addressed to M. Zelenski; volcangas@gmail.com

Received 25 June 2017; Revised 13 October 2017; Accepted 14 December 2017; Published 20 March 2018

Academic Editor: Joerg Goettlicher

Copyright (C) 2018 E. P. Shevko et al. This is an open access article distributed under the Creative Commons Attribution License, which permits unrestricted use, distribution, and reproduction in any medium, provided the original work is properly cited.

Native sulfur deposits on fumarolic fields at Ebeko volcano (Northern Kuriles, Russia) are enriched in chalcophile elements (As$\mathrm{Sb}-\mathrm{Se}-\mathrm{Te}-\mathrm{Hg}-\mathrm{Cu})$ and contain rare heavy metal sulfides $\left(\mathrm{Ag}_{2} \mathrm{~S}, \mathrm{HgS}\right.$, and $\left.\mathrm{CuS}\right)$, native metal alloys $\left(\mathrm{Au}_{2} \mathrm{Pd}\right)$, and some other lowsolubility minerals $\left(\mathrm{CaWO}_{4}, \mathrm{BaSO}_{4}\right)$. Sulfur incrustations are impregnated with numerous particles of fresh and altered andesite groundmass and phenocrysts (pyroxene, magnetite) as well as secondary minerals, such as opal, alunite, and abundant octahedral pyrite crystals. The comparison of elemental abundances in sulfur and unaltered rocks (andesite) demonstrated that rock-forming elements $(\mathrm{Ca}, \mathrm{K}, \mathrm{Fe}, \mathrm{Mn}$, and $\mathrm{Ti}$ ) and other lithophile and chalcophile elements are mainly transported by fumarolic gas as aerosol particles, whereas semimetals ( $\mathrm{As}, \mathrm{Sb}, \mathrm{Se}$, and $\mathrm{Te}$ ), halogens ( $\mathrm{Br}$ and I), and $\mathrm{Hg}$ are likely transported as volatile species, even at temperatures slightly above $100^{\circ} \mathrm{C}$. The presence of rare sulfides $\left(\mathrm{Ag}_{2} \mathrm{~S}, \mathrm{CuS}\right.$, and $\left.\mathrm{HgS}\right)$ together with abundant $\mathrm{FeS}$ in lowtemperature fumarolic environments can be explained by the hydrochloric leaching of rock particles followed by the precipitation of low-solubility sulfides induced by the reaction of acid solutions with $\mathrm{H}_{2} \mathrm{~S}$ at ambient temperatures. The elemental composition of native sulfur can be used to qualitatively estimate elemental abundances in low-temperature fumarolic gases.

\section{Introduction}

Volcanic fumaroles are surficial manifestations of magmatic degassing. Fumarolic gases mainly comprise the volatile components of $\mathrm{H}_{2} \mathrm{O}, \mathrm{CO}_{2}, \mathrm{SO}_{2}, \mathrm{HCl}$, and $\mathrm{HF}$, but hightemperature fumarolic gases $\left(>400^{\circ} \mathrm{C}\right)$ also commonly transport many metallic and nonmetallic compounds, which have sufficiently high vapor pressure at elevated temperatures. These include native elements, oxides, halides, and more complex compounds (e.g., [1-4]).

Rapid decrease in the temperature of gas at or near the surface, together with abrupt change from reducing to oxidizing conditions, results in the oversaturation of the transported volatile compounds. The latter precipitate inside or around fumaroles, forming black or colorful deposits, which are called sublimates. It has long been noticed that the zonation and compositions of high-temperature fumarolic sublimates are similar to those of ore bodies that form in magmatic environment $[2,5-7]$. Because the main component of the majority of fumarolic gases is water steam, they can be condensed in a special cooled flask. Such condensates often contain significant concentrations of metals (i.e., tens to hundreds of $\mathrm{ppm}$ ) and are used to study the gaseous transport of metals (e.g., $[4,5,8,9])$.

Low-temperature fumaroles (i.e., $200^{\circ} \mathrm{C}$ and lower) are not well-characterized in terms of their gaseous transport due to their generally low concentrations of metallic elements; the saturation vapor pressures of these elements decrease by 1-2 orders of magnitude for every hundred degrees. Very low metal contents in low-temperature condensates are often obscured by an overwhelming amount of colloidal sulfur $[10,11]$. Metals can be adsorbed by sulfur particles and are further deposited on the bottle (vial) walls. Because native sulfur can only be dissolved in hot aqua regia (which may 
introduce its own contaminants), the accurate analysis of lowtemperature gas condensates is a complex problem.

At the same time, metals and aerosol particles are transported by low-temperature gas and precipitate together with native sulfur around fumarole vents, forming wellknown yellow incrustations. These incrustations and even well-shaped sulfur crystals often contain mineral and rock inclusions, which were also carried by and deposited from fumarolic gas. Such sulfur can help to study the gases themselves. All components carried by the gas are inevitably found in fumarolic sulfur; therefore, the composition of the gas can be estimated at a qualitative level. Unfortunately, the quantitative analysis of this gas composition using fumarolic sulfur is impossible due to the strong fractionation of elements, including sulfur itself that occurs during the discharge of gas. Most of the sulfur and other metallic and nonmetallic elements escape fumarolic vents with the gas and are dissipated in the environment; thus, only a small (and unknown) fraction of these elements is deposited in incrustations.

The existing data on volcanic sulfur composition data have been obtained using mass-spectrometry (ICP-MS), atomic emission spectroscopy (ICP-AES), scanning electron microscopy with energy-dispersive spectroscopy (SEMEDS), reflectance spectrometry [12-15], and wet chemical methods [16]. For example, Kargel et al. [12] studied the trace element chemistry of native sulfur from a terrestrial volcanichydrothermal environment to determine the relationship between the color of sulfur and its trace element/trace mineral contents. A few tenths of a percent to a few percent of chalcophile trace elements (As, Se) commonly occur in sulfur and produce material with yellow, brown, orange, and red tints. Two-tenths of a percent to two percent of crystalline pyrite $\left(\mathrm{FeS}_{2}\right)$ commonly produces green, gray, and black volcanic sulfur. Specimens that have formed by direct deposition from vapor or by the melting/recrystallization of such deposits have a bright yellow color and the purest compositions.

Zeng et al. [15] analyzed the trace and rare earth element compositions of native sulfur "balls" from a hydrothermal field in Northeast Taiwan. They determined that their contents of Al, Ti, Rb, Cs, Ba, V, Cr, Co, Ni, Nb, Pb, Th, U, and REE were mostly derived from andesite; their contents of $\mathrm{Mg}, \mathrm{K}$, and $\mathrm{Mn}$ mostly originated from seawater; and their contents of $\mathrm{Fe}, \mathrm{Cu}, \mathrm{Zn}$, and $\mathrm{Ni}$ were partly derived from magma. Using sulfur composition data, they suggested a "glue pudding" growth model to explain the origin of these native sulfur balls. Goff et al. [16] studied various metals in native sulfur to determine the source of the gases at Sierra Negra and Alcedo volcanoes (Ecuador). The sulfur samples from these volcanoes have relatively high concentrations of As, $\mathrm{Hg}$, Se, $\mathrm{Te}$, and $\mathrm{Sb}$ and contain detectable amounts of $\mathrm{Ag}$.

Kim et al. examined sulfide and sulfosalt inclusions in molten sulfur from a submarine volcano (Lau Basin, Southwestern Pacific). This sulfur contained abundant inclusions of pyrite $\left(\mathrm{FeS}_{2}\right)$, covellite $(\mathrm{CuS})$, and $\mathrm{Cu}$-As sulfosalts, as well as measurable amounts of $\mathrm{Au}, \mathrm{Ag}, \mathrm{Ga}, \mathrm{Ge}, \mathrm{Tl}$, and other chalcophile elements. The high enrichment factors of these metals suggested that they originated from magma via volcanic degassing.

In the present work, we report new data on the chemical composition of native sulfur, leachates from native sulfur, and rare minerals as inclusions in native sulfur from Ebeko volcano (North Kuriles, Russian Far East) in order to understand the transport of elements in low-temperature fumarolic gases. Native sulfur from the volcano was studied using a variety of modern methods (including Synchrotron Radiation induced X-ray Fluorescence Spectroscopy (SR$\mathrm{XRF}$ ), leaching by water followed by ion chromatography and ICP-AES, and dissolution in carbon disulfide followed by SEM-EDS). Ebeko was chosen because of its accessibility as well as the fact that it features various and persistent fumarolic activity occurring at several fumarolic fields. Our data show that Ebeko sulfur is enriched in volatile chalcophile elements. The presence of rare sulfides (i.e., argentite, covellite, and cinnabar) and abundant pyrite may be fully explained by the acid leaching of rock particles followed by sulfide precipitation from leachates; that is, rock aerosols may serve as a source for chalcophile metals and iron.

\section{Study Area and Methods}

2.1. Ebeko Volcano and Fumaroles. Ebeko $\left(51.41^{\circ} \mathrm{N}, 176.01^{\circ} \mathrm{E}\right.$, $1156 \mathrm{~m}$ asl) is an active andesitic stratovolcano in the Kurile island arc, where the Pacific Plate is being subducted under the Okhotsk Plate. Ebeko is located in the northern part of Paramushir Island (Figure 1), $10 \mathrm{~km}$ from the town of Severo-Kurilsk. The summit of this volcano comprises four adjoining craters that are 250-300 m wide and 70-100 m deep and extend in the meridian direction. Several cold lakes are located in the Middle and South craters; a hot lake is located in the North crater.

Ebeko is characterized by occasional phreatomagmatic eruptions and abundant permanent fumaroles and thermal springs [17]. Between eruptions, the volcano exists in a state of strong and persistent fumarolic and hydrothermal activity. Numerous fumaroles are located inside craters and on the outer slopes of the cones (Figures 1 and 2). These fumaroles belong to four fumarolic fields: the NE fumarolic field (which is the largest field); the "July" fumarolic field; the South field; and the SE field. Fumaroles are encrusted with native sulfur of different colors, ranging from bright yellow to dark gray to pink (Figures 2 and 3), and reached a maximum height of $1.5 \mathrm{~m}$ during the time of sampling (Figure 2). The main component of Ebeko fumarolic gases is $\mathrm{H}_{2} \mathrm{O}$ (97-99 mol\%); the other components are $\mathrm{CO}_{2}, \mathrm{HCl}, \mathrm{SO}_{2}, \mathrm{H}_{2} \mathrm{~S}, \mathrm{~N}_{2}, \mathrm{Ar}, \mathrm{HF}, \mathrm{H}_{2}$, $\mathrm{CH}_{4}, \mathrm{CO}$, and $\mathrm{He}[18,19]$.

2.2. Field Sampling. Thirty samples of native sulfur (100-150 g each) were collected from the active and extinct fumaroles in the Northeast (NE), Southeast (SE), South, and July fumarolic fields at Ebeko volcano (Figure 1). Sulfur was collected from the inner parts of active fumaroles using a Teflon sampler (Figure 2). The samples were packed in plastic bags and transferred to the laboratory for analysis. Fumarolic temperatures were measured using a platinum LT300 Termex RTD thermometer. Twelve samples of fresh rocks 

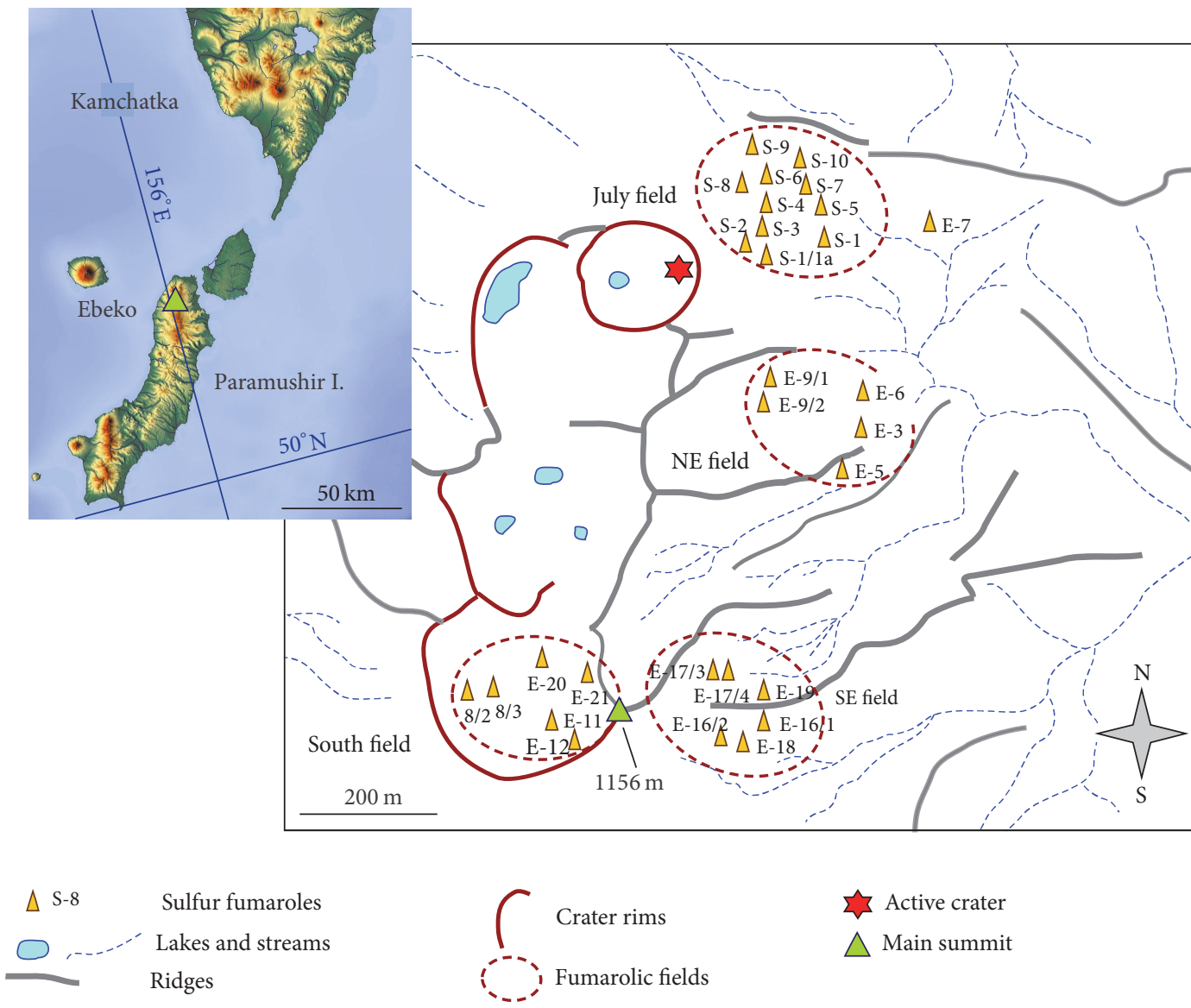

Active crater

$\triangle$ Main summit

FIGURE 1: Location of Ebeko volcano and a sampling scheme with fumarolic fields.

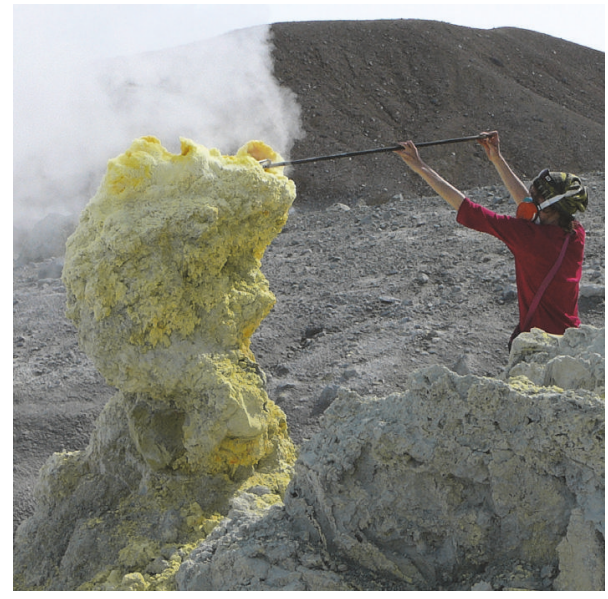

FIGURE 2: Fumarole edifice, the Southeast field, Ebeko volcano. Photo by T. Kotenko.

(andesite) were also collected from the crater and recent lava flows.

\subsection{Laboratory Measurements}

(1) SR-XRF Spectroscopy. Trace element concentrations in native sulfur and rocks were determined by analyzing pressed pellets of $30 \mathrm{mg}$ using Synchrotron Radiation induced X-ray
Fluorescence Spectroscopy (SR-XRF) at the synchrotron station VEPP-3 in the Budker Institute of Nuclear Physics SB RAS, Novosibirsk, Russia [20, 21]. The following analytical parameters were applied.

The VEPP-3 electron-positron storage ring and a wiggler with a magnetic field of $2 \mathrm{~T}$ were used; the electron beam energy of the storage ring was $2.00 \mathrm{GeV}$; and the typical electron current was $100 \mathrm{~mA}$. A silicon (111) single-crystal vacuum monochromator for the energy range of $5-47 \mathrm{keV}$ and an energy resolution $(\Delta E / E)$ of $1 \cdot 10^{-3}$ was employed; the beam size at the sample position was $2 \times 5 \mathrm{~mm}^{2}$. An Oxford Instruments $\mathrm{Si}(\mathrm{Li}) 10 \mathrm{~mm}^{2}$ detector, with a specified energy resolution of $133 \mathrm{eV}$ (at $5.9 \mathrm{keV}$ ), was also used.

The measurements were made using an irradiation energy of $30 \mathrm{KeV}$ for other elements; measuring time was $100 \mathrm{~s}$ per sample. This allowed us to increase signal/noise ratio for light elements. The peak areas of the analyzed and standard samples were normalized to the peak area of Compton scattering. Spectra processing was performed using the nonlinear least-square method using the AXIL-PC software (MS-DOS version [22]).

The matrix correction was performed as follows. The matrices of the studied samples and the external standard sample were almost identical. As no certified standards for native sulfur exist, we prepared our own standard. This standard comprised superpure native sulfur, with the addition of 


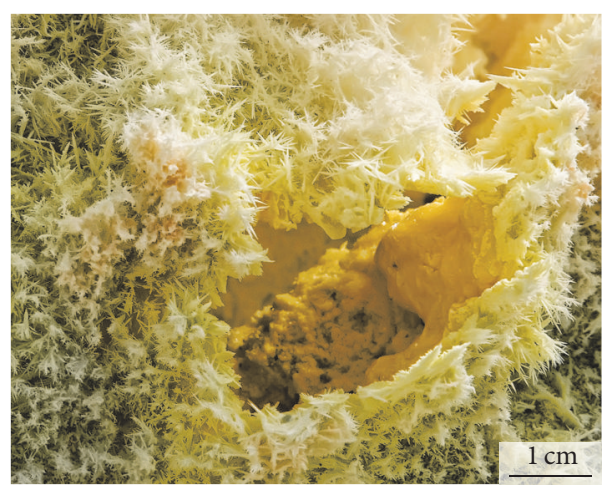

(a)

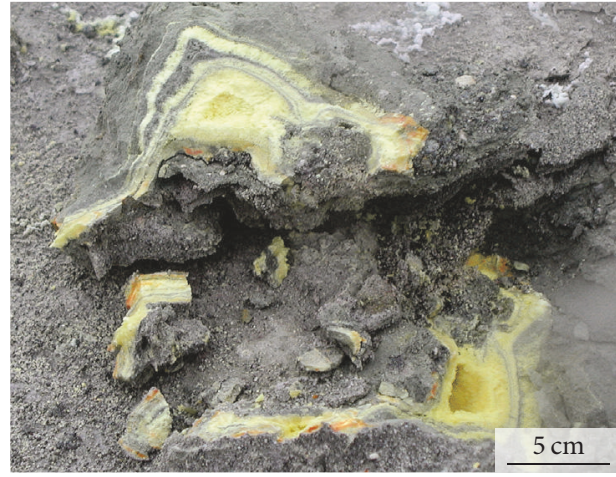

(b)

FIGURE 3: (a) Acicular sulfur crystals deposited from fumarolic gas; a gas channel covered with molten sulfur is visible. (b) Layered sulfur deposits of different colors around a fumarolic vent. The red color is due to arsenic and the greenish-gray color is due to dispersed pyrite crystals. South field, Ebeko volcano. Photos by M. Zelenski.

a $2.5 \% \mathrm{HCl}$ solution containing elements (e.g., As, $\mathrm{Sb}, \mathrm{Se}, \mathrm{Te}$, $\mathrm{Cd}, \mathrm{Zn}$, and $\mathrm{Cu}$ ) ranging in concentration from 10 to $100 \mathrm{ppm}$. After the addition of the solution aliquots, the sulfur powder was dried at $85^{\circ} \mathrm{C}$ to a constant weight. For the analyses, $30 \mathrm{mg}$ pellets that were six $\mathrm{mm}$ in diameter were molded [23]. The detection limits for the analyzed elements were $10 \mathrm{ppm}$ for $\mathrm{K}$, $\mathrm{Ca}, \mathrm{Ti}, \mathrm{Mn}$, and Fe; 0.1 ppm for Ni, Ga, Ge, Y, Zr, Sr, Rb, Nb, Th, and $\mathrm{U}$; and 0.05 ppm for $\mathrm{Cu}, \mathrm{Zn}, \mathrm{Ag}, \mathrm{Cd}, \mathrm{Pb}, \mathrm{Cr}, \mathrm{V}, \mathrm{Mo}, \mathrm{Sn}$, $\mathrm{As}, \mathrm{Se}, \mathrm{Sb}, \mathrm{Te}, \mathrm{Br}, \mathrm{I}$, and $\mathrm{Hg}$. The relative standard deviation of these measurements (RSD) was estimated at 15-20\% for most elements, with the exception of $\mathrm{Mn}$ and $\mathrm{Ti}$, which have some higher RSD because their concentrations are only slightly above detection limits.

(2) SEM-EDS Analyses. The selected grains of native sulfur were mounted on stubs and studied using an electron microscope with an EDS microanalyzer (LEO 143 OVP OXFORD, Institute of Geology and Mineralogy, Novosibirsk; Vega Tescan III, Institute of Experimental Mineralogy, Chernogolovka). The samples were studied using the following conditions: an accelerating voltage of $20 \mathrm{kV}$, a probe current of 300-400 pA, and a spot size of $100-200 \mathrm{~nm}$. The standards used for the EDS measurements in Chernogolovka are listed in Supplementary Table S1. Standardless EDS analysis was performed in Novosibirsk. Several sulfur samples were dissolved in carbon disulfide (CS2) and filtered; the insoluble residue was placed on carbon film and examined under an electron microscope. The latter technique allowed us to extract inclusions of heavy metal sulfides and other rare minerals impregnated within the sulfur matrix.

(3) Native Sulfur Leachates. To determine the contents of water-soluble elements in the fumarolic sulfur deposits, native sulfur was treated using bidistilled water immediately after sampling. Leachate solutions were obtained from a 1:10 sulfur-to-water ratio mixture (i.e., $10 \mathrm{~g}$ of the native sulfur was added to $100 \mathrm{~mL}$ of water); leaching duration was 24 hours. The leachates were filtered through $0.45 \mu \mathrm{m}$ Millipore filters and analyzed using ICP-AES (IRIS Advantage) at the Institute of Geology and Mineralogy, Novosibirsk. The detection limits for the elements analyzed using ICP-AES are listed in Supplementary Table S2. The contents of major anions $\left(\mathrm{Cl}^{-}, \mathrm{F}^{-}\right.$, and $\mathrm{SO}_{4}{ }^{2-}$ ) were measured using ion selective electrodes and ion chromatography (Institute of Volcanology and Seismology, Petropavlovsk-Kamchatsky).

\section{Results}

The results presented here include analyses of unaltered host rocks (andesites), analyses of fumarolic sulfur, analyses of sulfur leachates, and the SEM-EDS analyses of rare mineral inclusions in sulfur.

3.1. Rock Samples. Twelve rock samples were collected at the Ebeko summit and its vicinities, including fresh volcanic bombs from the recent 2009 eruption and samples from the lava flows downstream of the Kuzminka and Yurieva Rivers. All samples are two-pyroxene andesites. The phenocrysts include orthopyroxene, clinopyroxene, plagioclase, and $\mathrm{Ti}$ magnetite. The groundmass contains microlites of plagioclase, amphibole, abundant magnetite crystals, and felsic glass. Rare Cu-rich sulfide globules up to $20 \mu \mathrm{m}$ in size occur as inclusions in some pyroxene crystals.

The compositions of the analyzed Ebeko andesites are given in Table 1 (the average composition of 12 samples) and in Supplementary Table S3 (full results). In terms of their major and trace element abundances, the Ebeko andesites are similar to other Quaternary andesitic lavas from the Northern Kuriles [24].

3.2. Composition of Native Sulfur. Samples were collected from 30 sulfur fumaroles located on four different fumarolic fields (Figure 1) and examined for their contents of trace elements, leachable cations and anions, and trace minerals. The majority of the samples are bright yellow in color, although sulfur samples with greenish and red tints are not uncommon (Figure 3). These sulfur samples are typically fine powders; however, if the sulfur samples have experienced partial melting, they may be in the form of dense blocks. The 
TABLE 1: Average composition of Ebeko andesites*.

\begin{tabular}{|c|c|c|c|c|c|}
\hline Oxide & Wt.\% & Element & ppm & Element & ppm \\
\hline $\mathrm{SiO}_{2}$ & 58.1 & $\mathrm{Ag}$ & 0.40 & $\mathrm{Ni}$ & 26 \\
\hline $\mathrm{TiO}_{2}$ & 0.7 & As & 4.40 & $\mathrm{~Pb}$ & 8.1 \\
\hline $\mathrm{Al}_{2} \mathrm{O}_{3}$ & 17.3 & $\mathrm{Ba}$ & 422 & $\mathrm{Rb}$ & 44 \\
\hline $\mathrm{Fe}_{2} \mathrm{O}_{3}$ & 8.0 & $\mathrm{Br}$ & 2.0 & $\mathrm{Sb}$ & 0.44 \\
\hline $\mathrm{MnO}$ & 0.2 & $\mathrm{Cd}$ & 0.32 & $\mathrm{Se}^{* *}$ & 0.05 \\
\hline $\mathrm{MgO}$ & 3.3 & $\mathrm{Cr}$ & 51 & Sn & 1.7 \\
\hline $\mathrm{CaO}$ & 6.9 & Cs & 1.6 & $\mathrm{Sr}$ & 391 \\
\hline $\mathrm{Na}_{2} \mathrm{O}$ & 3.2 & $\mathrm{Cu}$ & 78 & $\mathrm{Te}^{* *}$ & 0.001 \\
\hline $\mathrm{K}_{2} \mathrm{O}$ & 2.2 & $\mathrm{Ga}$ & 13.8 & Th & 4.8 \\
\hline \multirow[t]{5}{*}{$\mathrm{P}_{2} \mathrm{O}_{5}$} & 0.20 & $\mathrm{Ge}$ & 2.4 & $\mathrm{U}$ & 1.6 \\
\hline & & $\mathrm{Hg}^{* *}$ & 0.08 & V & 133 \\
\hline & & I & 0.34 & $\mathrm{Y}$ & 21 \\
\hline & & Mo & 1.2 & $\mathrm{Zn}$ & 65 \\
\hline & & $\mathrm{Nb}$ & 2.25 & $\mathrm{Zr}$ & 109 \\
\hline
\end{tabular}

*Average of 12 analyses. ${ }^{* *}$ Taken from the "composition of average andesite," Voitkevich et al., 1990.

temperatures of fumarolic gas in the studied fumaroles range from 101 to $170^{\circ} \mathrm{C}$. The hottest fumaroles are located in the SE fumarolic field.

The most informative analysis was the SR-RXF analysis, which provided data for 31 elements (Table 2). The concentrations of the analyzed trace elements in sulfur vary from several $\mathrm{wt} \%(\mathrm{Fe})$ to a few ppm $(\mathrm{Cd}, \mathrm{Ag}$, and $\mathrm{Hg})$. In general, both more abundant elements $(\mathrm{Fe})$ and less abundant ones (Se, Te) are distributed nonuniformly, and their concentrations vary within a range of $1-3$ orders of magnitude from one fumarole to another. Elements such as $\mathrm{Zn}, \mathrm{Ag}, \mathrm{Cd}$, $\mathrm{Pb}, \mathrm{Ge}$, and Se have the highest concentrations in the July fumarolic field, whereas the concentrations of $\mathrm{Fe}$ and $\mathrm{Ti}$ in this field are the lowest. The concentrations of $\mathrm{K}, \mathrm{Th}$, and $\mathrm{U}$ have the smallest $\mathrm{max} / \mathrm{min}$ ratios (2.4-3.8) of all elements.

The lithophile elements $(\mathrm{Ca})$ and a number of chalcophile elements (e.g., $\mathrm{Cu}, \mathrm{Zn}, \mathrm{Ag}$, and $\mathrm{Cd}$ ) exhibit moderate correlations between each other (Figure 4(a)), thus suggesting that they share the same source. At the same time, volatile chalcophile elements (As, Sb, Se, and Te) and Fe, Mo, Sn, and $\mathrm{Pb}$ are poorly correlated with other chalcophile elements $(\mathrm{Cu}$, $\mathrm{Zn}, \mathrm{Ag}$, and Cd, Figure 4(c)).

3.3. Sulfur Leachates. Elements occur in sulfur in both waterinsoluble and water-soluble forms; the presence of the latter was confirmed via the treatment of sulfur using pure water followed by analyses of the resulting solutions (leachates). This was especially useful for the estimation of anion concentrations but also provided some additional information about cations. The compositions of the sulfur leachates are provided in Table 3. Leachates contain major anions $\left(\mathrm{F}^{-}, \mathrm{Cl}^{-}\right.$, and $\mathrm{SO}_{4}{ }^{2-}$ ), of which chloride is by far the most abundant. All major rock-forming elements ( $\mathrm{Si}, \mathrm{Ti}, \mathrm{Al}, \mathrm{Fe}, \mathrm{Ca}, \mathrm{Mg}, \mathrm{Na}$, and $\mathrm{K})$ were present in leachates, with $\mathrm{Na}^{+}, \mathrm{K}^{+}, \mathrm{Mg}^{2+}$, and $\mathrm{Ca}^{2+}$ being the main cations. Boron was the most abundant trace element (up to $84 \mathrm{ppm}$ in sample L-4). Unsurprisingly, nearly the same suite of trace lithophile and chalcophile elements as was measured in sulfur was observed in the analyzed sulfur leachates. Appreciable amounts of $\mathrm{PO}_{4}{ }^{2-}, \mathrm{B}, \mathrm{Ba}, \mathrm{Co}$, and $\mathrm{Bi}$ were measured only in sulfur leachates. However, the average elemental concentrations in sulfur and their corresponding elemental concentrations in sulfur leachates are poorly correlated (Figure 5). The elevated concentrations of $\mathrm{Ca}, \mathrm{Fe}, \mathrm{Ni}, \mathrm{Cu}, \mathrm{Zn}, \mathrm{I}, \mathrm{Y}, \mathrm{Zr}$, and $\mathrm{Cd}$ in leachates suggest that a significant fraction of these elements exist in sulfur in watersoluble forms (most likely as chlorides).

3.4. Rare Minerals in Fumarolic Sulfur. To examine the forms of occurrence of elements in native sulfur, we studied the samples using a scanning electron microscope with an Energy-Dispersive Spectrometer. Sulfur was studied: (1) as split unpolished pieces; (2) as polished pieces; and (3) after it was dissolved in carbon disulfide $\left(\mathrm{CS}_{2}\right)$ and its insoluble residue was examined. The last method provided the most interesting results because it allowed us to observe extremely rare inclusions.

The SEM-EDS analysis of trace minerals in sulfur is useful for two reasons. First, micron- and even submicron-sized mineral crystals composed of heavy elements are clearly visible under the electron microscope in back-scattered imaging mode (BSE) and can therefore be counted and studied. Second, very small and rare phases containing small amounts of elements can be reliably analyzed under an electron microscope, but such vanishingly low concentrations cannot be measured using conventional chemical or ICP-MS analyses. The list of the rare phases observed in the fumarolic sulfur of Ebeko volcano includes 21 rarely and moderately occurring minerals (Table 4, Figures 6 and 7) together with the major minerals of sulfur, opal, pyrite, and alunite. Sulfur incrustations also contain scattered crystals of rock-forming minerals (i.e., pyroxenes, plagioclase, and magnetite) and felsic glass. 


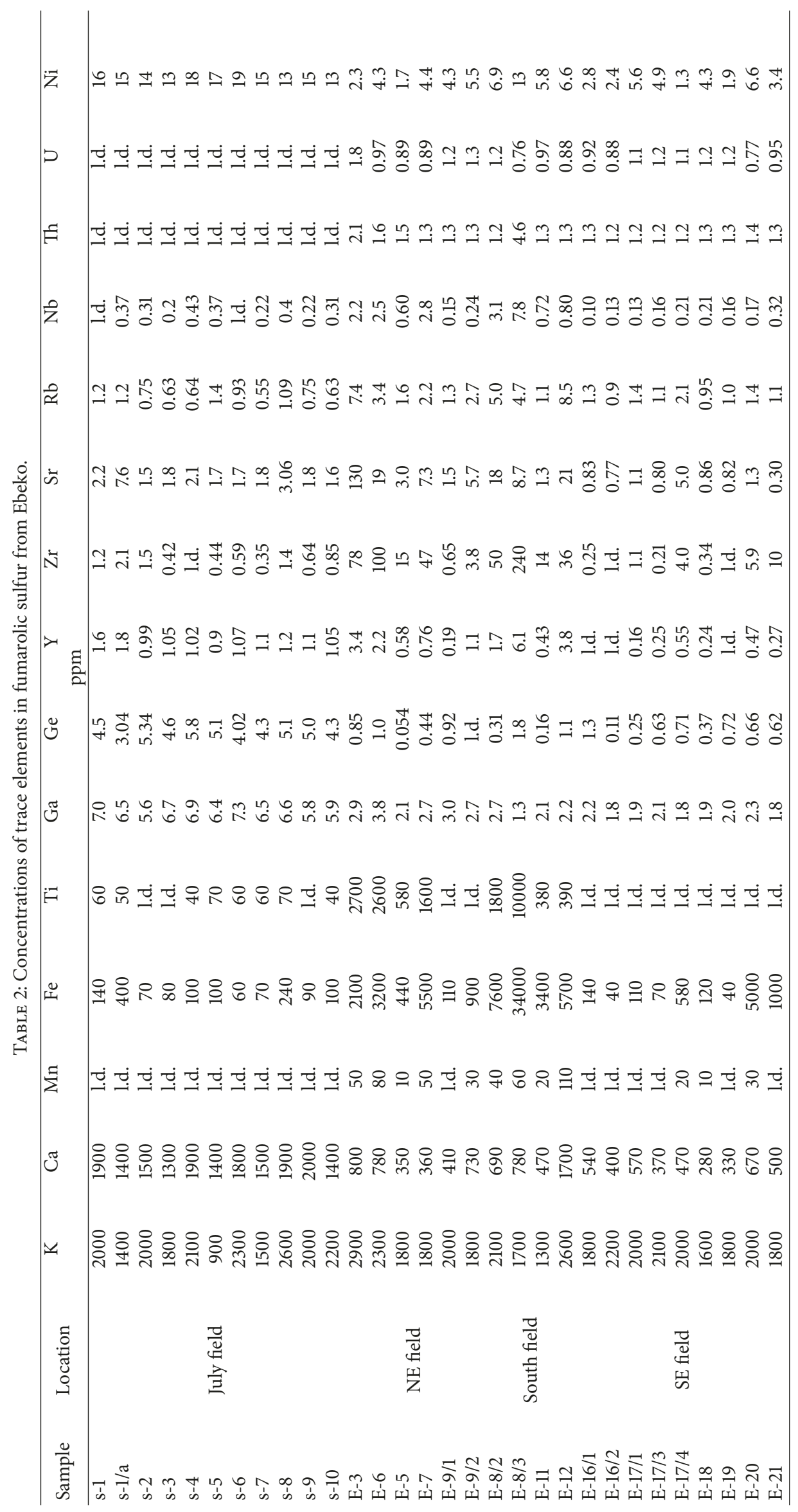




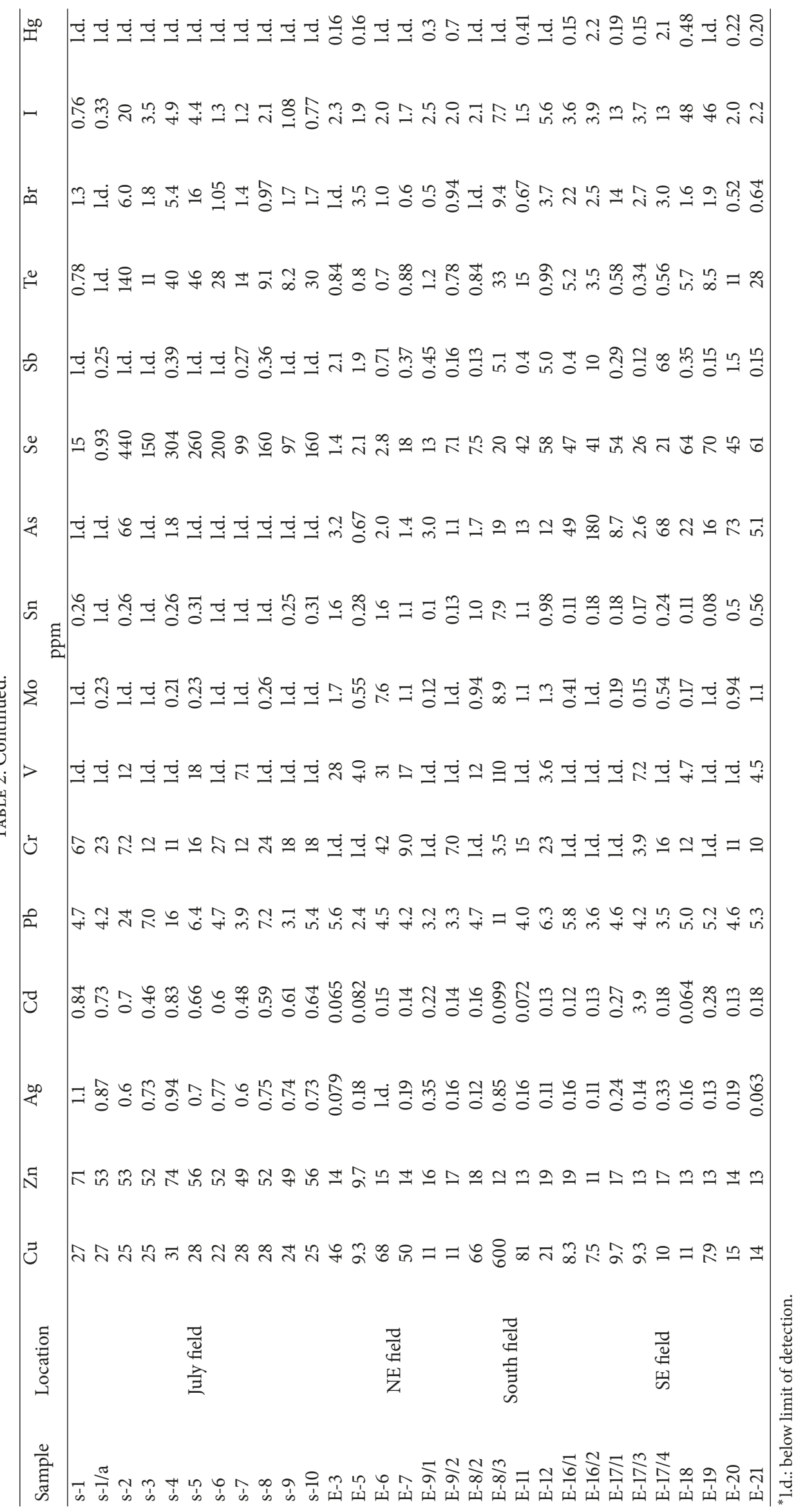




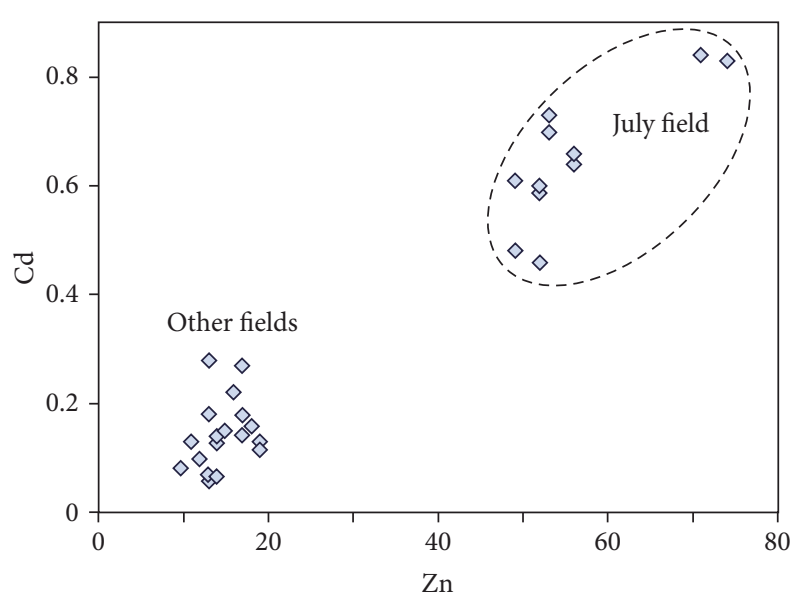

(a)

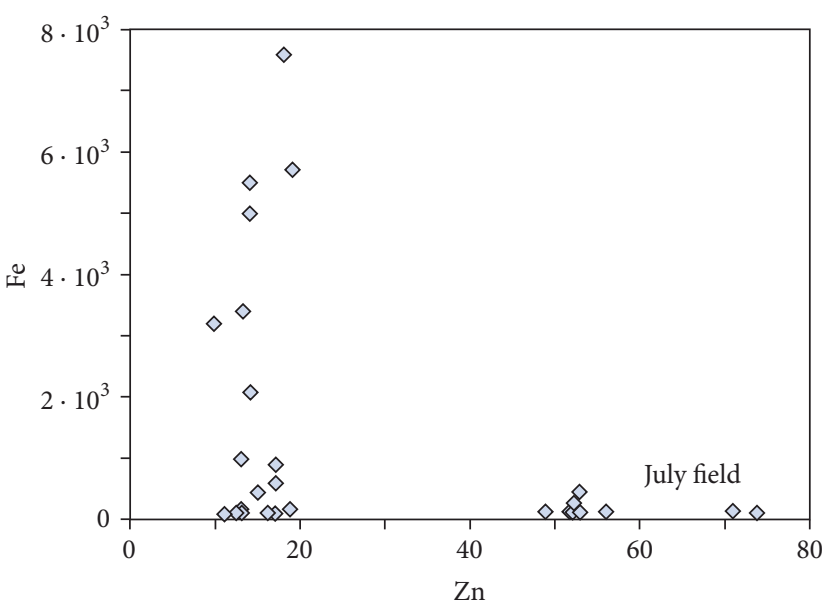

(c)

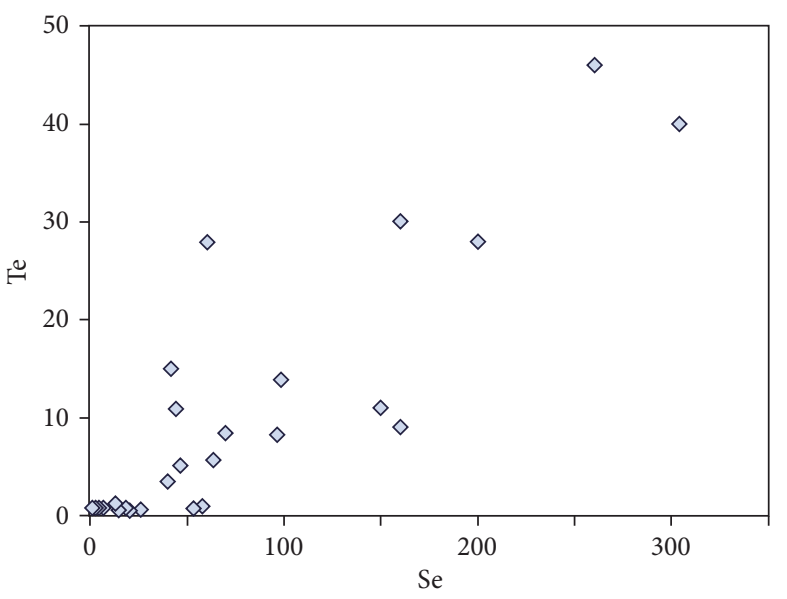

(b)

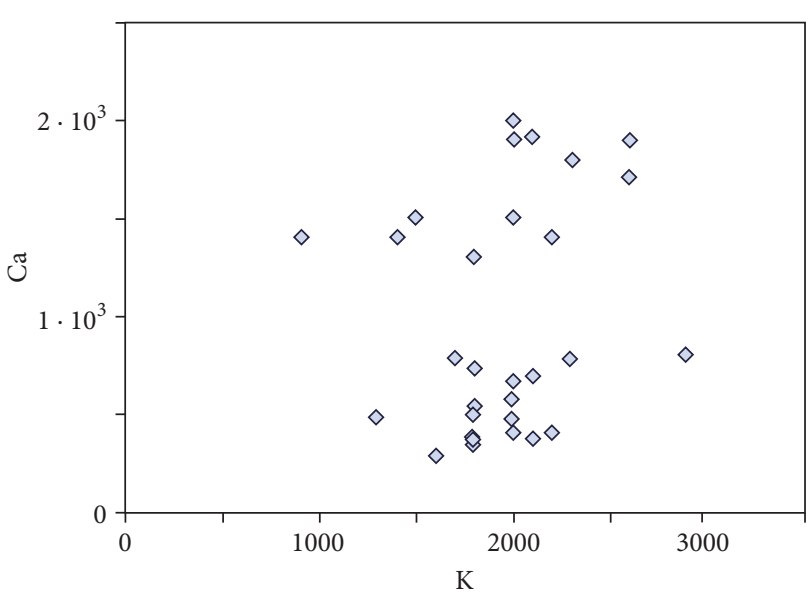

(d)

FIGURE 4: Variation diagrams for elements with different behaviors. (a) The chalcophile elements of $\mathrm{Zn}$ and Cd are moderately correlated between each other and have distinctly different concentrations in the July field (high) and in other fields (low). (b) The chalcophile elements of Se and Te are moderately correlated but exhibit no dependence on fumarolic fields. (c) Iron is not correlated with the chalcophile element $\mathrm{Zn}$ but has high concentrations in only one field. (d) The lithophile elements of $\mathrm{K}$ and $\mathrm{Ca}$ are not correlated.

Some rare phases were observed, such as palladium gold $\left(\mathrm{Au}_{2} \mathrm{Pd}\right)$ (Figure $\left.7(\mathrm{a})\right)$, native nickel $(\mathrm{Ni}, \mathrm{Fe})$, cadmoindite $\left(\mathrm{CdIn}_{2} \mathrm{~S}_{4}\right)$ (Figure $7(\mathrm{~b})$ ) [25], and famatinite $\left(\mathrm{Cu}_{3} \mathrm{SbS}_{4}\right)$ (Figure 7(f)). Significant amounts of iodine, as measured using ICP-AES and SR-XRF (Tables 2 and 3), are likely stored in a phase with an inferred composition of $\left(\mathrm{NH}_{4}\right) \mathrm{As}_{4} \mathrm{O}_{6} \mathrm{I}$ (Figure $7(\mathrm{e})$ ), which represents an iodine analogue $(20 \mathrm{wt} \% \mathrm{I})$ of the rare fumarolic mineral lucabindiite $\left(\left(\mathrm{K}_{\mathrm{N}} \mathrm{NH}_{4}\right) \mathrm{As}_{4} \mathrm{O}_{6}(\mathrm{Cl}, \mathrm{Br})\right)$ [26]. More abundant minerals included scheelite $\left(\mathrm{CaWO}_{4}\right)$ (Figure $\left.6(\mathrm{~h})\right)$, barite $\left(\mathrm{BaSO}_{4}\right)$ (Figure 6(g)), rutile $\left(\mathrm{TiO}_{2}\right)$ (Figures $6(\mathrm{f})$ and $6(\mathrm{~g})$ ), cotunnite $\left(\mathrm{PbCl}_{2}\right)$ (Figure $7(\mathrm{~h})$ ), cinnabar (HgS) (Figure $7(\mathrm{~d})$ ), and stibnite $\left(\mathrm{Sb}_{2} \mathrm{~S}_{3}\right)$. Octahedral pyrite $\left(\mathrm{FeS}_{2}\right)$ (Figure 6(c)) was the most abundant mineral in the sulfur incrustations after sulfur itself (Figures 3 and 6(a)) and opal (Figure 6(b)). Of the minerals listed above, opal, alunite, pyrite, and anhydrite are typical for low-temperature fumarolic incrustations. The occurrence of scheelite, famatinite, cinnabar, and especially native nickel, cadmoindite, and palladian gold is unusual and requires further study. For example, palladian gold could have originated from completely dissolved rock particles.

Silicate inclusions (particles) originating from wall rock (i.e., minerals, glass, and larger rock fragments) are sometimes abundant and reach $200-300 \mu \mathrm{m}$ or more in size. Such particles comprise the rock-forming elements of $\mathrm{Si}, \mathrm{Ti}, \mathrm{Al}$, $\mathrm{Fe}, \mathrm{Ca}, \mathrm{K}$, and $\mathrm{Na}$, also contain $\mathrm{H}_{2} \mathrm{O}, \mathrm{F}^{-}, \mathrm{Cl}^{-}$, and $\mathrm{SO}_{4}{ }^{2-}$, and occur as trapped materials within the sulfur matrix. After the silicate particles were completely leached by hydrochloric acid, only opal $\left(\mathrm{SiO}_{2} \cdot \mathrm{nH}_{2} \mathrm{O}\right)$ and rutile $\left(\mathrm{TiO}_{2}\right)$ remained as insoluble residue (Zelenski \& Taran 2011), which explains the presence of these two phases in the samples. The enrichment of trace elements in red sulfur can be attributed to As-Sbsulfide inclusions. Covellite (CuS) inclusions were observed in gray sulfur from the NE and SE fields. The SEM-EDS analyses confirmed that the high concentrations of $\mathrm{Ag}, \mathrm{As}, \mathrm{Sb}, \mathrm{Cu}$, and $\mathrm{Pb}$ in native sulfur (Table 2) can be explained by the presence of corresponding sulfides within the sulfur matrix. 
TABLE 3: Concentrations of anions and cations in sulfur leachates.

\begin{tabular}{|c|c|c|c|c|c|c|c|c|c|}
\hline \# & L-1 & L-2 & L-3 & L-4 & L-5 & L-6 & L-7 & L-8 & L-9 \\
\hline Location & \multicolumn{4}{|c|}{ SE field } & \multicolumn{2}{|c|}{ July field } & \multicolumn{3}{|c|}{ NE field } \\
\hline $\mathrm{pH}$ & 0.88 & 0.54 & 0.73 & 1.1 & 1.8 & 1.9 & 1.8 & 1.8 & 1.8 \\
\hline & \multicolumn{9}{|c|}{ ppm } \\
\hline $\mathrm{F}^{-}$ & 0.0032 & 0.047 & 0.042 & 0.24 & l.d. & 1.d. & 1.d. & 1.d. & 1.d. \\
\hline $\mathrm{SO}_{4}{ }^{2-}$ & 120 & 30 & 290 & 22 & 38 & 42 & 8 & 19 & 5.6 \\
\hline $\mathrm{Cl}^{-}$ & 6400 & 19000 & 12000 & 6000 & 2.8 & 9.5 & 130 & 1090 & 38 \\
\hline $\mathrm{SiO}_{2}$ & 0.19 & 0.69 & 0.77 & 3.7 & 1.1 & 20 & 28 & 1.7 & 17 \\
\hline $\mathrm{Al}$ & 1.1 & 0.804 & 0.72 & 0.97 & 0.3 & 7.7 & 5.5 & 12 & 2.2 \\
\hline As & 1.7 & 4.8 & 4.2 & 8.6 & 0.035 & 0.033 & 0.013 & 0.023 & 0.011 \\
\hline B & 21 & 36 & 54 & 84 & 0.086 & 0.19 & 0.038 & 0.33 & 0.02 \\
\hline $\mathrm{Ba}$ & 0.065 & 0.032 & 0.016 & 0.019 & 0.01 & 0.1 & 0.066 & 0.032 & 0.0078 \\
\hline $\mathrm{Bi}$ & 0.24 & 0.4 & 0.37 & 1.1 & 0.035 & 1.4 & 0.406 & 0.22 & 0.15 \\
\hline $\mathrm{Ca}$ & 1.5 & 1.8 & 1.4 & 2.8 & 1.4 & 8.8 & 3.5 & 9.9 & 1.9 \\
\hline Co & 0.0083 & 0.014 & 0.0012 & 0.013 & 0.002 & 0.024 & 0.019 & 0.0061 & 0.0078 \\
\hline $\mathrm{Cr}$ & 0.809 & 1.7 & 0.84 & 0.62 & 0.002 & 0.066 & 0.303 & 0.054 & 0.13 \\
\hline $\mathrm{Cu}$ & 0.17 & 0.3 & 0.302 & 0.93 & 0.049 & 1.2 & 0.172 & 0.17 & 0.12 \\
\hline $\mathrm{Fe}$ & 8.3 & 15 & 9.1 & 8.5 & 0.35 & 5.8 & 6.5 & 14 & 4.4 \\
\hline $\mathrm{Ga}$ & 0.076 & 0.0472 & 0.21 & 0.026 & 0.035 & 0.033 & 0.013 & 0.023 & 0.011 \\
\hline I & 1.9 & 1.1 & 6.2 & 13 & 0.6 & 0.67 & 0.27 & 0.47 & 0.2 \\
\hline $\mathrm{K}$ & 0.4 & 0.39 & 0.29 & 0.35 & 0.18 & 0.45 & 0.68 & 1.1 & 0.3 \\
\hline $\mathrm{Mg}$ & 0.29 & 0.27 & 0.45 & 0.51 & 0.15 & 0.84 & 0.6 & 1.5 & 0.39 \\
\hline $\mathrm{Mn}$ & 0.6 & 1.3 & 0.72 & 0.58 & 0.034 & 0.57 & 0.27 & 0.57 & 0.21 \\
\hline $\mathrm{Na}$ & 1.3 & 1.6 & 1.3 & 1.7 & 2.9 & 4.2 & 5 & 2.5 & 1.4 \\
\hline $\mathrm{Ni}$ & 0.35 & 0.58 & 0.49 & 0.55 & 0.022 & 1.5 & 0.29 & 0.77 & 0.44 \\
\hline $\mathrm{Pb}$ & 0.36 & 0.48 & 0.33 & 0.25 & 0.035 & 0.0709 & 0.027 & 0.063 & 0.042 \\
\hline $\mathrm{Sb}$ & 0.2 & 0.094 & 0.4 & 1.1 & 0.07 & 0.067 & 0.027 & 0.047 & 0.022 \\
\hline Sn & 0.032 & 0.047 & 0.034 & 0.14 & 0.035 & 0.033 & 0.013 & 0.023 & 0.011 \\
\hline $\mathrm{Sr}$ & 0.037 & 0.0089 & 0.009 & 0.019 & 0.009 & 0.087 & 0.052 & 0.12 & 0.024 \\
\hline $\mathrm{Ti}$ & 0.209 & 0.14 & 0.17 & 0.12 & 0.004 & 0.075 & 0.05 & 0.042 & 0.016 \\
\hline $\mathrm{V}$ & 0.0064 & 0.0075 & 0.0072 & 0.0054 & 0.002 & 0.021 & 0.024 & 0.024 & 0.0043 \\
\hline \multirow[t]{2}{*}{$\mathrm{Zn}$} & 0.38 & 0.61 & 0.55 & 0.91 & 0.13 & 0.82 & 0.2 & 0.25 & 0.085 \\
\hline & \multicolumn{9}{|c|}{$\mathrm{ppb}$} \\
\hline $\mathrm{Cd}$ & 36 & 2.8 & 2 & 1.9 & 2 & 2.7 & 0.8 & 1.4 & 0.7 \\
\hline $\mathrm{Li}$ & 1.9 & 2.8 & 2 & 1.9 & 2 & 4.7 & 2.8 & 1.9 & 1.6 \\
\hline $\mathrm{Y}$ & 1.9 & 1.9 & 1.4 & 1.9 & 1.4 & 2.7 & 1 & 2.9 & 0.9 \\
\hline $\mathrm{Zr}$ & 3.8 & 3.8 & 3 & 4.5 & 1 & 2 & 0.8 & 1.9 & 0.7 \\
\hline
\end{tabular}

\section{Discussion}

4.1. Relative Elemental Abundances in Sulfur and Transport Modes in Fumarolic Gases. Due to the extremely low vapor pressures of the majority of metallic element compounds below $200^{\circ} \mathrm{C}$ (e.g., $[2,27]$ ), direct analyses of low-temperature condensates can provide inconclusive results. On the other hand, the composition of gas and the composition of fumarolic incrustations are directly linked, as the latter is formed by the direct deposition of elements from the gas or the precipitation of aerosol particles. Therefore, the trace element composition of fumarolic sulfur can be used as an indicator of the presence of elements in low-temperature fumarolic gas in any form, and the relationships between these elements can be used to evaluate the forms of elemental transport. Unfortunately, this can only provide a rough estimate of the fumarolic gas composition because of the strong and unknown fractionation of elements that occurs in the gas when it reaches the surface. First, it is not known how much sulfur is deposited from the gas.

It has long been known that elements can be transported within fumarolic gases either as gaseous species or in the form of fine rock aerosol (e.g., [3]). To assess the contributions of these two forms to the total amount of an element, the socalled enrichment factor (EF) was introduced [28-30] and has since been used in many studies of volcanic and fumarolic gases (e.g., $[2,3,5])$. This approach works well if the aerosol composition is well known, for example, if the aerosol comprises fine rock particles [31].

Similar results can be achieved using the so-called titration method if we would subtract small fractions of rock from the total composition of the incrustations. When the concentration of the chosen reference element approaches zero, it can be concluded that the correct amount of titrant 
TABLE 4: Phase list and occurrence frequencies of minerals in fumarolic sulfur from Ebeko.

\begin{tabular}{|c|c|c|}
\hline Composition & Name & Occurrence \\
\hline $\mathrm{Ag}_{2} \mathrm{~S}$ & Argentite & Moderate \\
\hline $\mathrm{As}_{4} \mathrm{~S}_{4}$ & Realgar & Moderate \\
\hline $\mathrm{Au}_{2} \mathrm{Pd}$ & Palladian gold & Single \\
\hline $\mathrm{BaSO}_{4}$ & Barite & Moderate \\
\hline $\mathrm{B}(\mathrm{OH})_{3}$ & Sassolite & Rare \\
\hline $\mathrm{CaF}_{2}$ & Fluorite & Rare \\
\hline $\mathrm{CaSO}_{4}$ & Anhydrite & Moderate \\
\hline $\mathrm{CaWO}_{4}$ & Scheelite & Moderate \\
\hline $\mathrm{CdIn}_{2} \mathrm{~S}_{4}$ & Cadmoindite & Rare \\
\hline$(\mathrm{Cu}, \mathrm{Sn}) \mathrm{S}$ & Copper-tin sulfide & Rare \\
\hline $\mathrm{Cu}_{3} \mathrm{SbS}_{4}$ & Famatinite & Rare \\
\hline $\mathrm{CuS}$ & Covellite & Rare \\
\hline $\mathrm{Cu} 2 \mathrm{~S}$ & Chalcocite & Rare \\
\hline $\mathrm{FeS}_{2}$ & Pyrite & Major \\
\hline $\mathrm{HgS}$ & Cinnabar & Rare \\
\hline $\mathrm{KAl}_{3}\left(\mathrm{SO}_{4}\right)_{2}(\mathrm{OH})_{6}$ & Alunite & Major \\
\hline$\left(\mathrm{NH}_{4}\right) \mathrm{As}_{4} \mathrm{O}_{6}(\mathrm{I})$ & Iodine-lucabindiite & Rare \\
\hline $\mathrm{Ni}, \mathrm{Fe}, \mathrm{S}$ & Native nickel & Single \\
\hline $\mathrm{PbCl}_{2}$ & Cotunnite & Moderate \\
\hline $\mathrm{PbSO}_{4}$ & Anglesite & Rare \\
\hline S & Native sulfur & Major \\
\hline $\mathrm{Sb}_{2} \mathrm{~S}_{3}$ & Stibnite & Rare \\
\hline $\mathrm{SiO}_{2} * \mathrm{nH}_{2} \mathrm{O}$ & Opal & Major \\
\hline $\mathrm{TiO}_{2}$ & Rutile & Moderate \\
\hline \multirow[t]{5}{*}{$\mathrm{ZrSiO}_{4}$} & Zircon & Moderate \\
\hline & Pyroxene & Moderate \\
\hline & Plagioclase & Moderate \\
\hline & Magnetite & Moderate \\
\hline & Glass & Moderate \\
\hline
\end{tabular}

(rock) has been subtracted and that all remaining elements have originated from a source other than rock aerosol. This approach was implemented on the plot shown in Figure 8, which depicts the concentrations of 31 analyzed elements in the fumarolic sulfur of Ebeko compared to the concentrations of elements in $5 \%$ of the rock, that is, such concentrations that would be in sulfur if it contained $5 \mathrm{wt} \%$ of rock aerosol. For each element, the ranges of its concentrations in all studied fumaroles and its average value are shown. The ratio of the concentration of the element in sulfur to the concentration of the element in " $5 \%$ rock" approximately corresponds to the classical conception of EF, using the maximum concentration of calcium as a reference.

The plot in Figure 8 demonstrates that the concentrations of the most abundant rock-forming elements $(\mathrm{Fe}, \mathrm{Ca}, \mathrm{K}, \mathrm{Ti}$, and $\mathrm{Mn}$ ) as well as those of $\mathrm{Sr}, \mathrm{V}$, and $\mathrm{Zr}$ can be explained by the presence of rock particles in sulfur, whereas the concentrations of $\mathrm{Cu}$ and $\mathrm{Zn}$ only slightly exceed those in the rock. Other chalcophile elements, such as $\mathrm{Cd}, \mathrm{Ag}, \mathrm{Hg}$, Se, $\mathrm{Te}, \mathrm{As}, \mathrm{Sb}$, and $\mathrm{Pb}$, as well as bromine and iodine, have average and minimum concentrations in sulfur that exceed their concentrations in rock particles ("5\% rock") by at least $1-2$

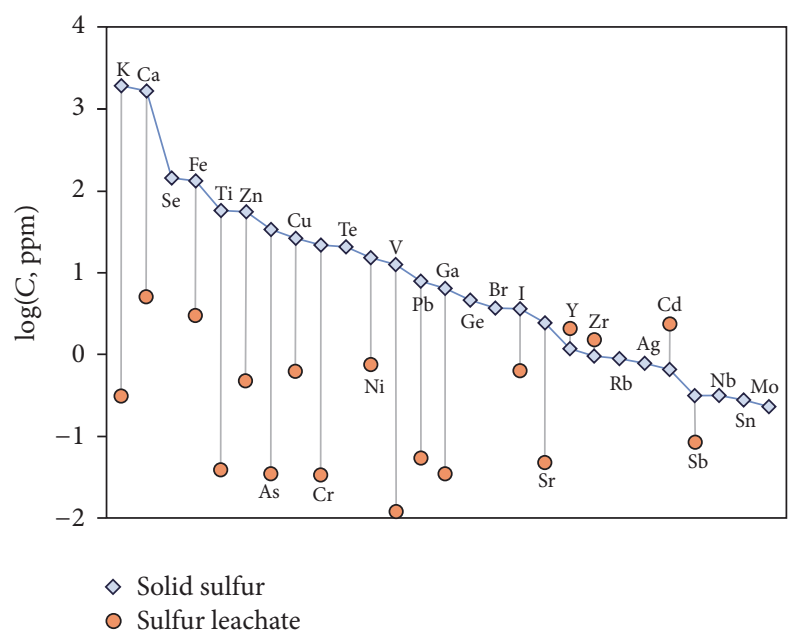

FIGURE 5: Average elemental concentrations in solid sulfur (July fumarolic field) compared to corresponding elemental concentrations in sulfur leachates from the same field. Elements are arranged from high to low average concentrations in sulfur.

orders of magnitude. This does not definitely mean that the listed ten elements are transported as gaseous species: in low-temperature fumarolic gas, they can also occur as fine aerosols of condensed volatile species.

The ratios of the average elemental concentrations in sulfur to the elemental concentrations in " $5 \%$ rock" are plotted on a separate graph (Figure 9) and are arranged in descending order. This graph is similar to the classical graph of enrichment factors (e.g., [31]). Tellurium and selenium have local enrichments of up to $10^{6}$, followed by As, Sb, and I (local enrichments $\left.=10^{3}-10^{4}\right)$. Some elements, such as $\mathrm{Hg}, \mathrm{Cd}, \mathrm{Ag}$, and $\mathrm{Ge}$, have lower values $\left(10^{2}-10^{3}\right)$, of which germanium is rarely analyzed and considered in this context. Rock-forming elements demonstrate the lowest enrichments, with calcium not being enriched at all.

In the case of low-temperature fumaroles, approaches such as enrichment factors or rock titration may be less accurate than when applied to high-temperature gases because (1) the majority of aerosols are particles of altered rocks with unknown compositions and (2) aerosol particles continue to change their compositions after they are deposited in incrustations because they are affected by low-temperature acid condensates of fumarolic gases containing hydrochloric and sulfuric acids. The concentrations of any reference element in low-temperature incrustations can arbitrarily change because of acid alteration (see below), which will eventually decrease the accuracy of the calculations. Additionally, the "enrichment factor conception" does not allow distinguishing between the volatile transport of elements and the transport of condensed volatile species that were gaseous at higher temperatures but condensed somewhere in a fumarolic channel beneath the surface (e.g., sulfides and chlorides of chalcophile elements).

4.2. Acid Alteration and Origin of Sulfide Minerals in Ebeko Sulfur. Although the direct deposition of sulfides from hightemperature fumarolic gas is a phenomenon that frequently 


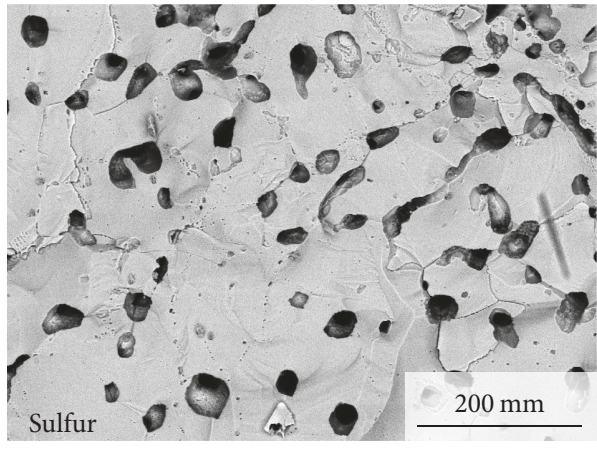

(a)

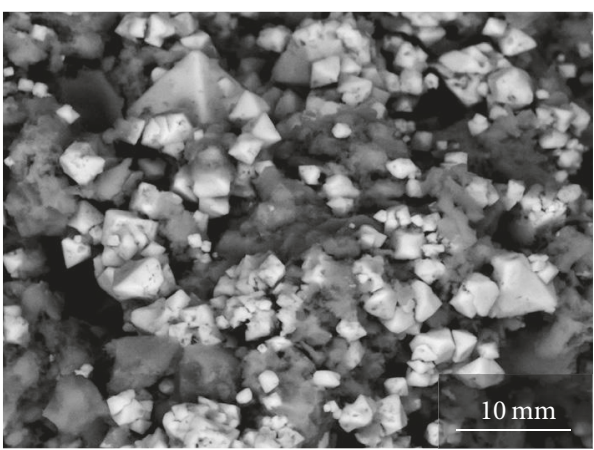

(c)

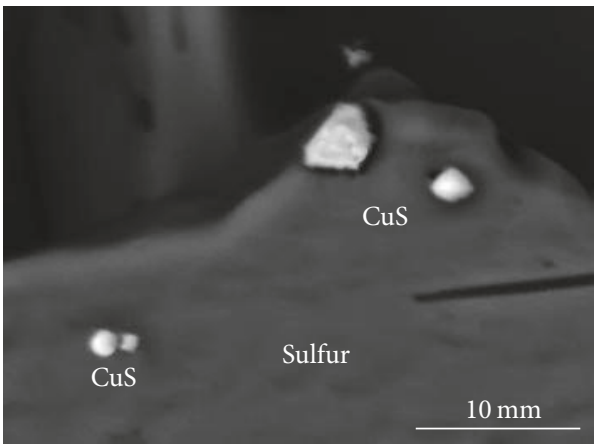

(e)

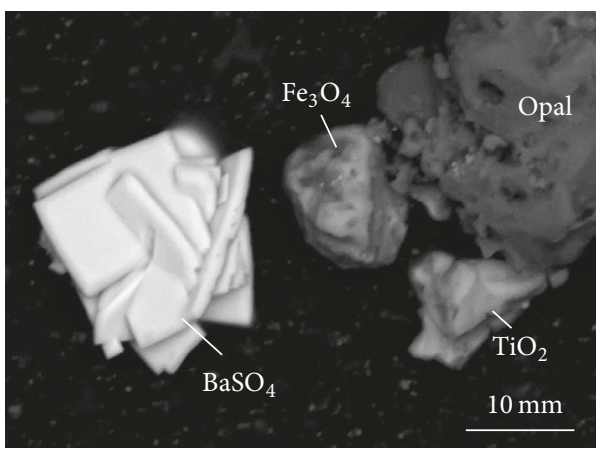

(g)

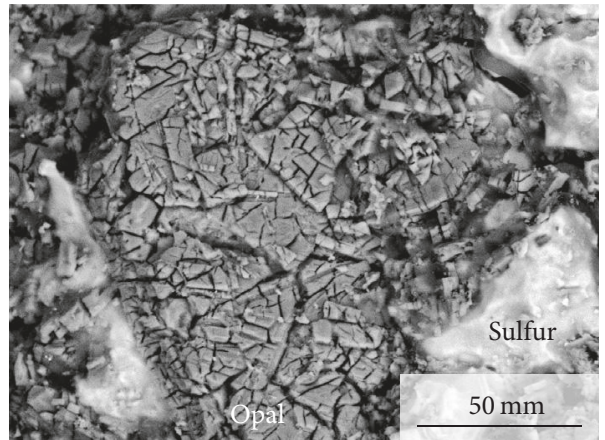

(b)

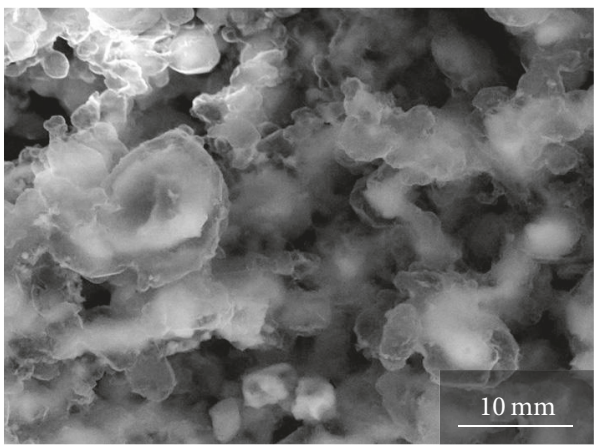

(d)

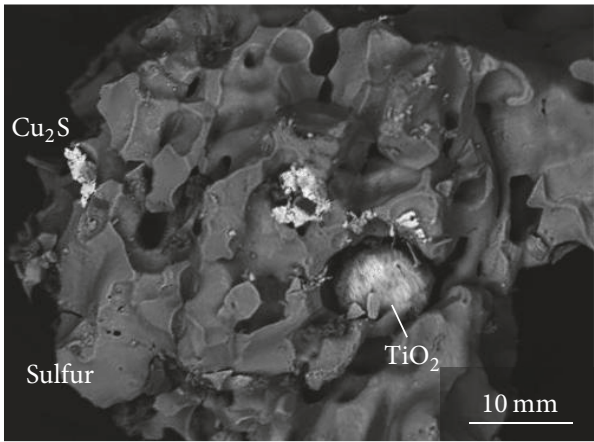

(f)

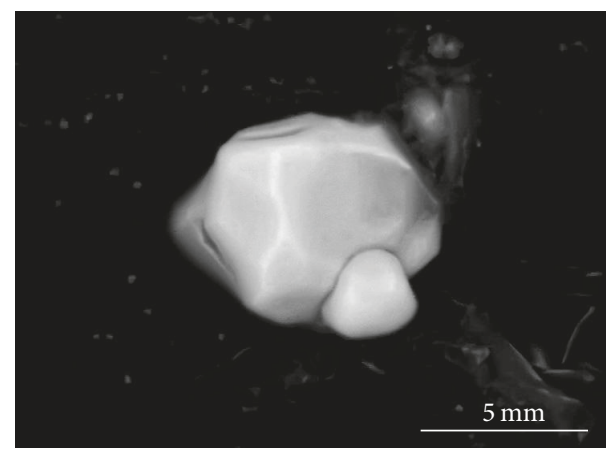

(h)

FIGURE 6: Major and rare phases from fumarolic incrustations of Ebeko volcano. (a) Molten and solidified sulfur with "cheese texture." (b) Opal with contraction cracks surrounded by sulfur. (c) Octahedral pyrite crystals mixed with silicate particles. (d) Aggregate of sassolite $\left(\mathrm{H}_{3} \mathrm{BO}_{3}\right)$ crystals. (e) Covellite $(\mathrm{CuS})$ crystals on sulfur. (f) Chalcocite $\left(\mathrm{Cu}_{2} \mathrm{~S}\right)$ aggregates and a particle of $\mathrm{TiO}_{2}$ (rutile?) inside a pore. (g) Barite, magnetite, rutile, and opal aggregates extracted from sulfur. (h) Euhedral crystals of scheelite. SEM BSE images. 


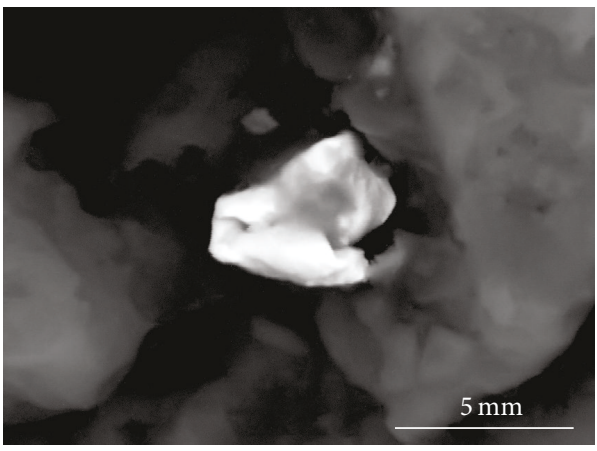

(a)

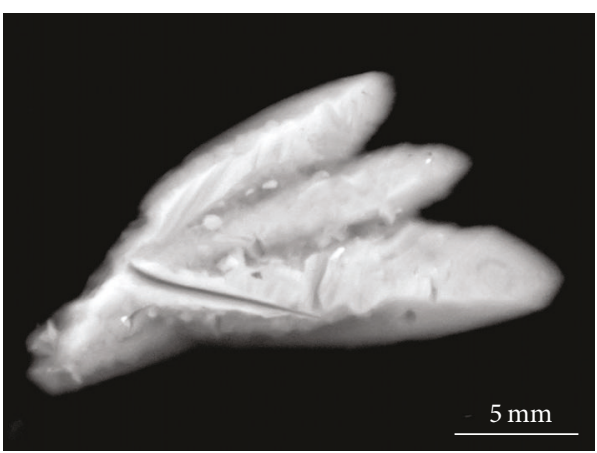

(c)

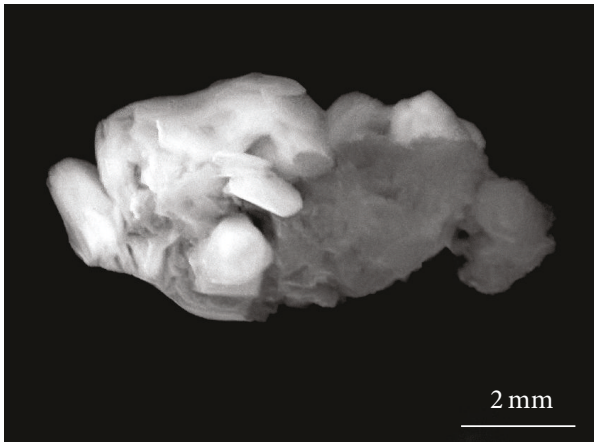

(e)

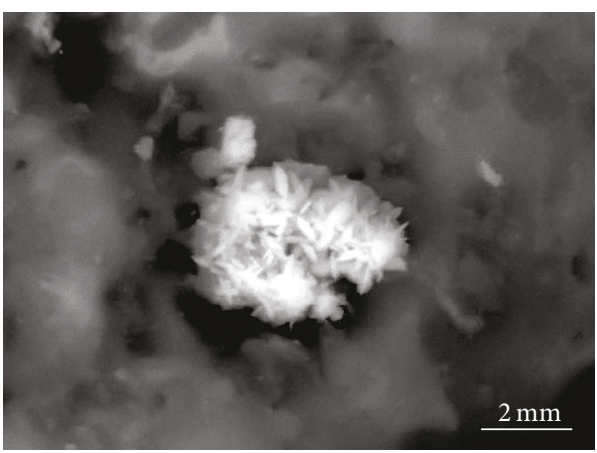

(g)

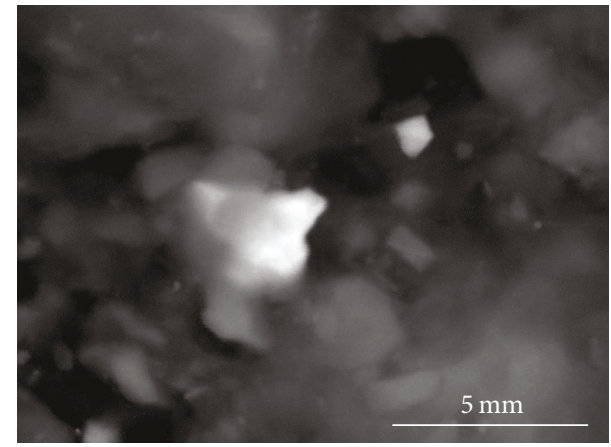

(b)

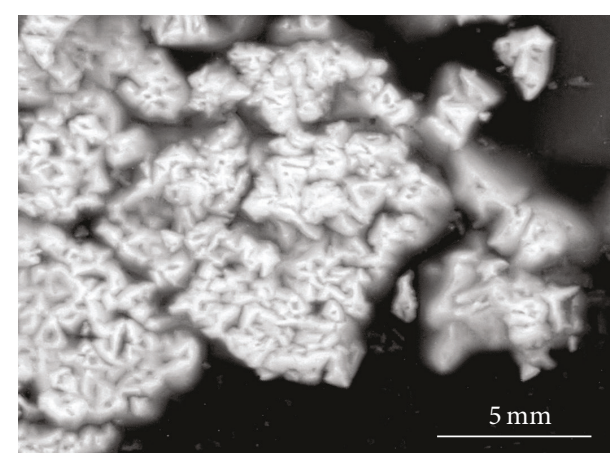

(d)

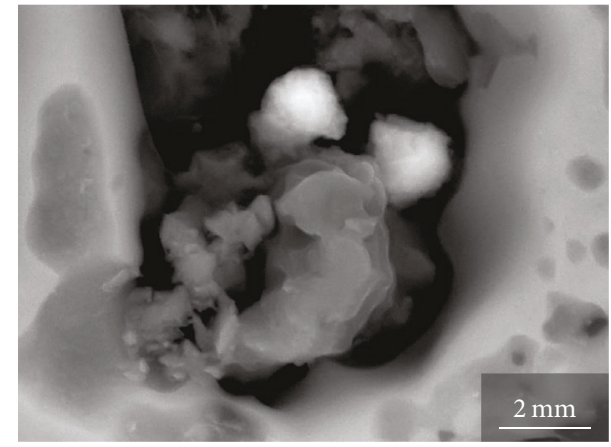

(f)

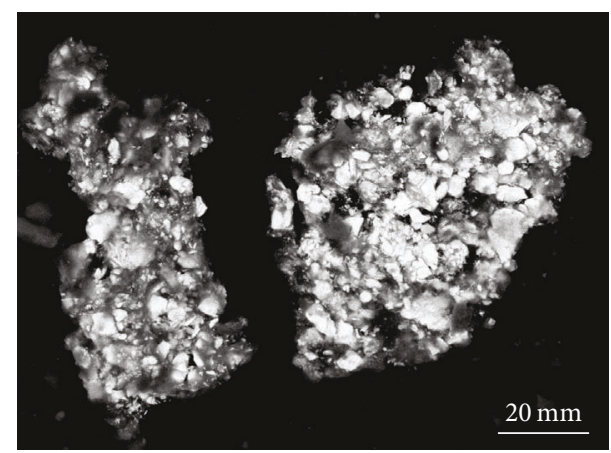

(h)

FiguRE 7: Rare phases from fumarolic incrustations of Ebeko volcano. (a) Small aggregate of palladian gold attached to sulfur surface. (b) Aggregate and a single crystal of cadmoindite $\left(\mathrm{CdIn}_{2} \mathrm{~S}_{4}\right)$ on sulfur surface. (c) Aggregate of argentite $\left(\mathrm{Ag}_{2} \mathrm{~S}\right)$ crystals. (d) Aggregate of cinnabar (HgS) crystals. (e) Crystals of $\left(\mathrm{NH}_{4}\right) \mathrm{As}_{4} \mathrm{O}_{6} \mathrm{I}$ (white) attached to sulfur (gray). (f) Two globules of famatinite $\left(\mathrm{Cu}_{3} \mathrm{SbS}_{4}\right)($ white) surrounded by sulfur (light gray) and alunite (gray). (g) Aggregate of $\mathrm{Cu}-\mathrm{Sn}$ sulfide (white) on sulfur surface (gray). (h) Aggregate of cotunnite ( $\mathrm{PbCl}_{2}$ ) (white crystals) mixed with silicate particles. SEM BSE images. 


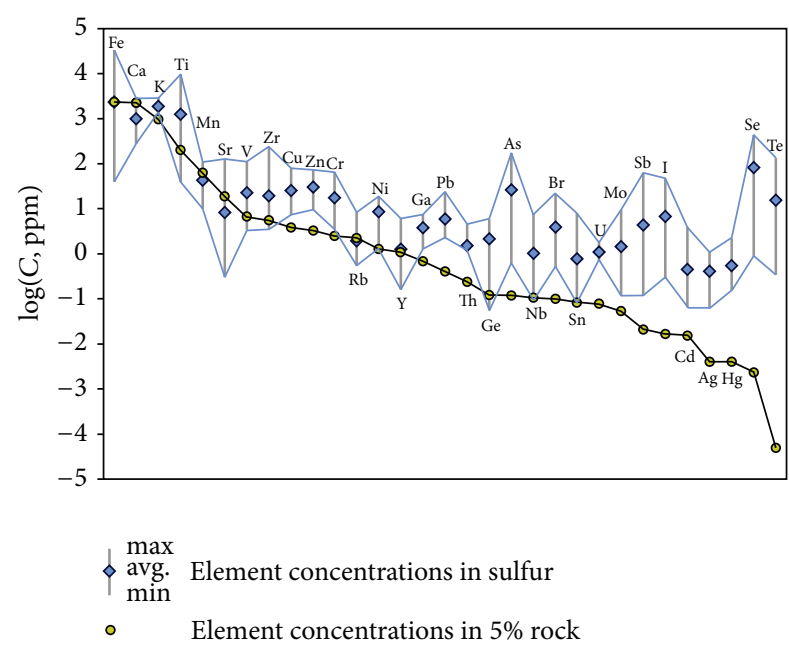

Figure 8: Elemental concentrations in sulfur compared to their corresponding concentrations in " $5 \%$ rock" (Ebeko andesites). The "5\% rock" approximates the contribution of rock particles to the composition of fumarolic incrustations. For each element, its minimum, maximum, and average concentrations are shown. Elements are arranged from high to low concentrations in rock (Ebeko andesite). The distance in log units on the plot between a point showing the concentration of an element in sulfur and a point showing the concentration of the same element in " $5 \%$ rock" corresponds to the "enrichment factor" for this element.

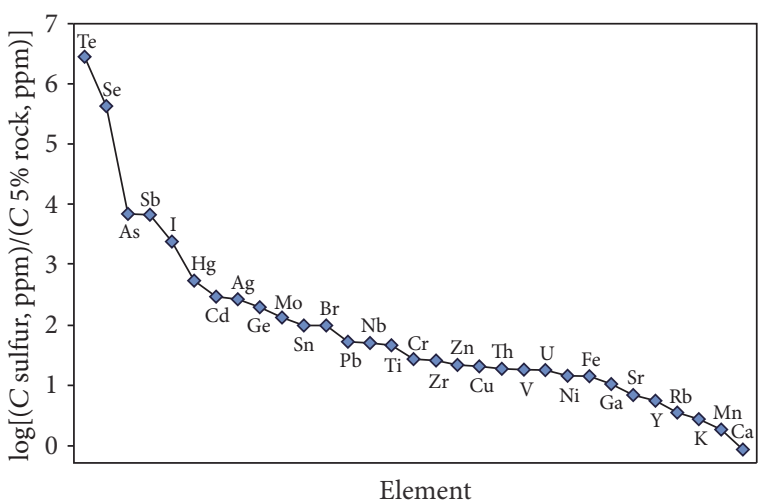

FIGURE 9: Logarithms of elemental ratios $C$ (sulfur)/ $C$ (5\% rock), similar to enrichment factors (see details in text).

occurs on volcanoes $[1,2,32]$ (Taran et al. 2000), this process is not necessarily required for sulfide formation in a low-temperature fumarolic environment. The hydrochloric leaching of rock particles followed by the saturation of acid solutions with $\mathrm{H}_{2} \mathrm{~S}$ may possibly explain the occurrence of abundant pyrite and rare $\mathrm{Cu}, \mathrm{Ag}, \mathrm{Hg}$, In, $\mathrm{Sn}$, and $\mathrm{Sb}$ sulfides in the Ebeko sulfur. It has been shown that the acid leaching of silicate rocks by hydrochloric acid $(\mathrm{HCl})$ can completely extract all cations, except for silicon and partially titanium, from a rock particle (e.g., [33] and references therein). The hydrochloric leaching of fumarolic incrustations differs from sulfate acid leaching, which is also common on volcanoes $[34,35]$ but is similar to water-rock interaction that occurs within acid volcanic lakes and enriches the latter in rockforming and trace elements [36-38].
Fumarolic gases condense upon cooling to produce acid solutions at temperatures below or slightly above the boiling point of pure water at a given hypsometric level $\left(\sim 99^{\circ} \mathrm{C}\right.$ for Ebeko). If this condensation occurs in the absence of air (e.g., inside a fumarolic edifice similar to that shown in Figure 2), the resulting liquid will contain $\mathrm{HCl}, \mathrm{HF}, \mathrm{H}_{2} \mathrm{SO}_{3}$, and variable amounts of polythionic acids (e.g., [39]). The most aggressive of these is hydrochloric acid, which, in hot solutions, extracts all metals from a silicate matrix (titanium to a lesser extent), while $\mathrm{HF}$ attacks the silicate matrix itself. Silicon and titanium form opal with rutile globules (Figures 6(a), 6(b), and 6(g)), whereas a solution of metal chlorides cools and further interacts with the $\mathrm{H}_{2} \mathrm{~S}$ from ascending fumarolic gases. As a result of such interactions, sulfides of metals with lowsolubility products can precipitate from cold acid solutions. High chloride concentrations $(19 \mathrm{~g} / \mathrm{l})$ and low $\mathrm{pH}$ values (0.54, Table 2$)$ confirm the presence of hydrochloric acid solutions in the Ebeko fumaroles.

It is known from chemistry that a compound will form a precipitate if the ion product $\mathrm{Q}$ in the solution is greater than the solubility product of the compound Ksp: $\mathrm{Me}^{2+}(\mathrm{aq})$ $+\mathrm{S}^{2-}(\mathrm{aq})=\mathrm{MeS} \downarrow$. Because $\mathrm{H}_{2} \mathrm{~S}$ is a weak acid, the $\mathrm{pH}$ of the solution affects the concentrations of sulfide ions $\mathrm{S}^{2-}(\mathrm{aq})$ in the solution: $\mathrm{S}^{2-}(\mathrm{aq})+\mathrm{H}_{3} \mathrm{O}^{+}(\mathrm{aq})=\mathrm{HS}^{-}(\mathrm{aq})+\mathrm{H}_{2} \mathrm{O}$; $\mathrm{HS}^{-}(\mathrm{aq})$ $+\mathrm{H}_{3} \mathrm{O}^{+}(\mathrm{aq})=\mathrm{H}_{2} \mathrm{~S}$. Strong acid $(\mathrm{HCl})$ removes $\mathrm{S}^{2-}(\mathrm{aq})$ ions from the solution, and the ion product $\mathrm{Q}=\left[\mathrm{Me}^{2+}(\mathrm{aq})\right] \times$ $\left[\mathrm{S}^{2-}(\mathrm{aq})\right]$ decreases. Only sulfides with low Ksp (e.g., HgS, $\mathrm{Ag}_{2} \mathrm{~S}$ ) can precipitate from solutions with low $\mathrm{pH}$, whereas elements that form sulfides with higher Ksp remain dissolved. This phenomenon has been widely used in analytical chemistry to separate ions of different metals. For example, Hillebrand et al. [40] suggested the following solubility order of metal sulfides: $\mathrm{As}_{2} \mathrm{~S}_{3}<\mathrm{MoS}_{2}<\mathrm{HgS}<\mathrm{Ag}_{2} \mathrm{~S}<\mathrm{CuS}<\mathrm{Sb}_{2} \mathrm{~S}_{3}<$ $\mathrm{Bi}_{2} \mathrm{~S}_{3}<\mathrm{SnS}_{2}<\mathrm{CdS}<\mathrm{PbS}<\mathrm{SnS}$.

The behavior of a metal sulfide can be estimated more precisely based on its solubility product Ksp (Supplementary Table S4). For example, the Ksp of $\mathrm{FeS}_{2}\left(\mathrm{Fe}^{2+}, \mathrm{S}_{2}{ }^{2-}\right)$ is $6.3 E-$ 31 , which is much lower than the Ksp of $\mathrm{FeS}\left(\mathrm{Fe}^{2+}, \mathrm{S}^{2-}\right)$, which is equal to $5 E-18$. This explains why pyrite $\left(\mathrm{FeS}_{2}\right)$ is a common mineral in fumarolic fields, whereas iron sulfide (FeS) dissolves easily even in diluted hydrochloric acid. The Ksp of cinnabar $(4 E-53)$ is lower than that of metacinnabar $(1.6 E-52)$, from which follows the fact that the occurrence of cinnabar in fumarolic incrustations is more plausible. The very low Ksp of GeS ( $3 E-35)$ may explain the noticeable enrichment of Ebeko sulfur in germanium (Table 2), which can be stored in germanium sulfide. It is most likely that the precipitation of sulfides from acid solutions occurs in the lowtemperature zone of incrustations at ambient temperatures because the solubility product of sulfides increases by 1-3 orders of magnitude for every 10 degrees [41]. A similar mechanism was proposed to explain the occurrence of disseminated sulfides in sulfur spherules from Kawah Ijen crater lake [42]. They suggested that the sulfide saturation of pyrite and enargite $\left(\mathrm{Cu}_{3} \mathrm{AsS}_{4}\right)$ occurred directly in acidic waters $(\mathrm{pH}$ $=0.4$ ) and was induced by upward-streaming $\mathrm{H}_{2} \mathrm{~S}$-bearing gases. A sketch in Figure 10 illustrates the described processes that occur in low-temperature fumaroles. 


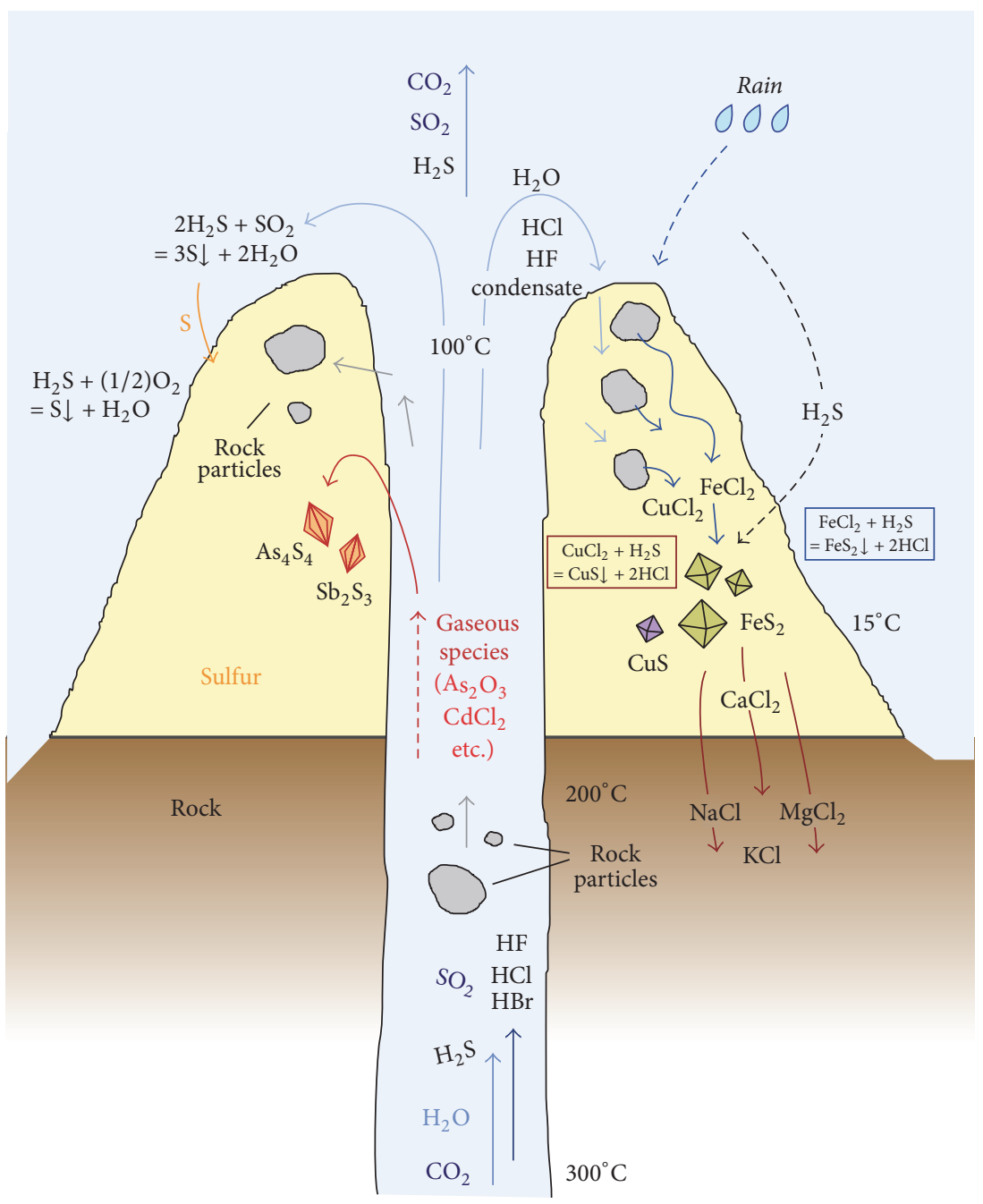

Figure 10: Chemical processes in low-temperature sulfur fumaroles. Fumarolic gases (mainly $\mathrm{H}_{2} \mathrm{O}, \mathrm{CO}_{2}, \mathrm{SO}_{2}, \mathrm{H}_{2} \mathrm{~S}$, and $\mathrm{HCl}$ ) carry volatile metal species and some amount of rock aerosol. At the fumarole vent, the temperature abruptly decreases and volatile species condense, forming solid phases and acid condensate that is enriched in $\mathrm{HCl}$, while $\mathrm{H}_{2} \mathrm{~S}$ mainly escapes. Sulfur is precipitated due to the reaction between $\mathrm{H}_{2} \mathrm{~S}$ and $\mathrm{SO}_{2}$ and the partial oxidation of $\mathrm{H}_{2} \mathrm{~S}$. Hot acid condensate can attack rock particles, extracting metals. Then, the condensate cools to ambient temperature and the chlorides of metals (e.g., $\mathrm{CuCl}_{2}, \mathrm{FeCl}_{2}$ ) from the acid solution react with $\mathrm{H}_{2} \mathrm{~S}$ to form insoluble sulfides. Petrogenic elements do not form sulfides, and their chlorides are washed away from incrustations by atmospheric precipitates.

Whereas elements with insoluble sulfides are retained in sulfur incrustations, petrogenic elements (i.e., $\mathrm{Na}, \mathrm{K}, \mathrm{Mg}, \mathrm{Ca}$, $\mathrm{Al}$, and partially $\mathrm{Fe}$ ) can be washed away under lowtemperature conditions $\left(<100^{\circ} \mathrm{C}\right)$ by atmospheric precipitation due to the solubility of their chlorides. $\mathrm{Ca}$ and $\mathrm{Al}$ may be partially retained in the presence of $\mathrm{H}_{2} \mathrm{SO}_{4}$ in forms gypsum/anhydrite and alunite. Such rinsing may significantly decrease the concentrations of $\mathrm{Ca}$ and $\mathrm{Mg}$ in incrustations, thus making the calculations of the enrichment factors or rock titration less reliable (see previous section). In fact, if a nonvolatile reference element is depleted, then these calculations will show enrichment in all other elements. Thus, for low-temperature incrustations, other reference elements or other calculation methods should be implemented in further studies.

\section{Conclusions}

(1) Low-temperature sulfur incrustations from Ebeko volcano contain appreciable amounts of trace elements stored in rock particles, metal sulfides (e.g., argentite $\left(\mathrm{Ag}_{2} \mathrm{~S}\right)$, covellite $(\mathrm{CuS})$, cadmoindite $\left(\mathrm{CdIn}_{2} \mathrm{~S}_{4}\right)$, famatinite $\left.\left(\mathrm{Cu}_{3} \mathrm{SbS}_{4}\right)\right)$, chlorides (cotunnite $\left(\mathrm{PbCl}_{2}\right)$ ), sulfates (anhydrite $\left(\mathrm{CaSO}_{4}\right)$, alunite $\left(\mathrm{KAl}_{3}\left(\mathrm{SO}_{4}\right)_{2}(\mathrm{OH})_{6}\right)$, anglesite $\left(\mathrm{PbSO}_{4}\right)$, barite $\left.\left(\mathrm{BaSO}_{4}\right)\right)$, and tungstates (scheelite $\left.\left(\mathrm{CaWO}_{4}\right)\right)$. Native sulfur, opal, alunite, and pyrite are the major minerals in these incrustations. The SR-XRF analysis of native sulfur represents a reliable analysis that does not require complex digesting procedures.

(2) Because fumarolic incrustations are derived from cooling gas, their compositions can be used to assess the composition of this gas. This approach was implemented for the 
low-temperature fumaroles of Ebeko volcano, whose gas contains extremely low concentrations of volatile metal species; thus, the data obtained directly from gas condensates may be inconclusive. Rock titration was used to assess the modes of transport of different elements. Only ten elements (Cd, Ag, $\mathrm{Hg}$, Se, Te, As, Sb, Pb, Br, and I) are sufficiently enriched in sulfur to suggest that they experienced gaseous transport. All other elements, including the chalcophile elements of $\mathrm{Cu}$ and $\mathrm{Zn}$, originated from rock particles.

(3) Ultra-acid and hot $\left(\mathrm{pH} \sim 0.5 ; \sim 100^{\circ} \mathrm{C}\right)$ gas condensates attack rock particles impregnated in fumarolic sulfur, which results in the extraction of cations from the aforementioned particles. At lower (ambient) temperatures, such cations in solution further interact with fumarolic $\mathrm{H}_{2} \mathrm{~S}$ to precipitate rare, low-solubility sulfides $\left(\mathrm{Ag}_{2} \mathrm{~S}, \mathrm{HgS}\right.$, and $\left.\mathrm{CuS}\right)$ as well as abundant pyrite $\left(\mathrm{FeS}_{2}\right)$. The silicate matrix remaining after this acid leaching forms opal with rare inclusions of $\mathrm{TiO}_{2}$. The concentrations of petrogenic elements (i.e., $\mathrm{Na}, \mathrm{K}, \mathrm{Mg}, \mathrm{Ca}, \mathrm{Al}$, and $\mathrm{Fe}$ ) in sulfur incrustations can be significantly decreased by acid leaching followed by washing away with atmospheric precipitation.

\section{Conflicts of Interest}

The authors declare that they have no conflicts of interest.

\section{Acknowledgments}

The authors are grateful to T. A. Kotenko and L. V. Kotenko for their helpful logistical support during fieldwork. Financial support for this study was provided by the Russian Science Foundation (Grant no. 16-17-10145). Fieldwork was supported by the Russian State Assignment Project 0330-2016-0001.

\section{Supplementary Materials}

The supplementary materials file contains four supplementary tables. Table 1: used standards for EDS analysis. Table 2: detection limits for ICP-AES analysis. Table 3: compositions of Ebeko andesites. Table 4: solubility products of some lowsoluble sulfides. (Supplementary Materials)

\section{References}

[1] A. Bernard and F. Le Guern, "Condensation of volatile elements in high-temperature gases of Mount St. Helens," Journal of Volcanology and Geothermal Research, vol. 28, no. 1-2, pp. 91$105,1986$.

[2] R. B. Symonds, W. I. Rose, M. H. Reed, F. E. Lichte, and D. L. Finnegan, "Volatilization, transport and sublimation of metallic and non-metallic elements in high temperature gases at Merapi Volcano, Indonesia," Geochimica et Cosmochimica Acta, vol. 51, no. 8, pp. 2083-2101, 1987.

[3] R. B. Symonds and M. H. Reed, "Calculation of multicomponent chemical equilibria in gas-solid- liquid systems: calculation methods, thermochemical data, and applications to studies of high-temperature volcanic gases with examples from Mount St. Helens," American Journal of Science, vol. 293, no. 8, pp. 758864, 1993.
[4] Y. A. Taran, A. Bernard, J.-C. Gavilanes, E. Lunezheva, A. Cortés, and M. A. Armienta, "Chemistry and mineralogy of high-temperature gas discharges from Colima volcano, Mexico. Implications for magmatic gas-atmosphere interaction," Journal of Volcanology and Geothermal Research, vol. 108, no. 1-4, pp. 245-264, 2001.

[5] Y. A. Taran, J. W. Hedenquist, M. A. Korzhinsky, S. I. Tkachenko, and K. I. Shmulovich, "Geochemistry of magmatic gases from Kudryavy volcano, Iturup, Kuril Islands," Geochimica et Cosmochimica Acta, vol. 59, no. 9, pp. 1749-1761, 1995.

[6] J. W. Hedenquist and J. B. Lowenstern, “The role of magmas in the formation of hydrothermal ore deposits," Nature, vol. 370, no. 6490, pp. 519-527, 1994.

[7] A. E. Williams-Jones and C. A. Heinrich, "100th Anniversary Special Paper: Vapor transport of metals and the formation of magmatic-hydrothermal ore deposits," Economic Geology, vol. 100, no. 7, pp. 1287-1312, 2005.

[8] J. B. Gemmell, "Geochemistry of metallic trace elements in fumarolic condensates from Nicaraguan and Costa Rican volcanoes," Journal of Volcanology and Geothermal Research, vol. 33, no. 1-3, pp. 161-181, 1987.

[9] J. P. Quisefit, J. P. Toutain, G. Bergametti, M. Javoy, B. Cheynet, and A. Person, "Evolution versus cooling of gaseous volcanic emissions from Momotombo Volcano, Nicaragua: Thermochemical model and observations," Geochimica et Cosmochimica Acta, vol. 53, no. 10, pp. 2591-2608, 1989.

[10] T. P. Fischer, S. Shuttleworth, and P. A. O’Day, "Determination of trace and platinum-group elements in high ionic-strength volcanic fluids by sector-field Inductively Coupled Plasma Mass Spectrometry (ICP-MS)," Fresenius' Journal of Analytical Chemistry, vol. 362, no. 5, pp. 457-464, 1998.

[11] F. Sortino, A. Nonell, J. P. Toutain, M. Munoz, M. Valladon, and G. Volpicelli, "A new method for sampling fumarolic gases: Analysis of major, minor and metallic trace elements with ammonia solutions," Journal of Volcanology and Geothermal Research, vol. 158, no. 3-4, pp. 244-256, 2006.

[12] J. S. Kargel, P. Delmelle, and D. B. Nash, "Volcanogenic Sulfur on Earth and Io: Composition and Spectroscopy," Icarus, vol. 142, no. 1, pp. 249-280, 1999.

[13] Z. Zeng, C. Liu, C. A. Chen et al., "Origin of a native sulfur chimney in the Kueishantao hydrothermal field, offshore northeast Taiwan," Science China Earth Sciences, vol. 50, no. 11, pp. 1746-1753, 2007.

[14] J. Kim, K.-Y. Lee, and J.-H. Kim, "Metal-bearing molten sulfur collected from a submarine volcano: Implications for vapor transport of metals in seafloor hydrothermal systems," Geology, vol. 39, no. 4, pp. 351-354, 2011.

[15] Z. Zeng, C.-T. A. Chen, X. Yin et al., "Origin of native sulfur ball from the Kueishantao hydrothermal field offshore northeast Taiwan: Evidence from trace and rare earth element composition," Journal of Asian Earth Sciences, vol. 40, no. 2, pp. 661-671, 2011.

[16] F. Goff, G. M. McMurtry, D. Counce, J. A. Simac, A. R. RoldánManzo, and D. R. Hilton, "Contrasting hydrothermal activity at Sierra Negra and Alcedo volcanoes, Galapagos Archipelago, Ecuador," Bulletin of Volcanology, vol. 62, no. 1, pp. 34-52, 2000.

[17] I. V. Melekescev, V. N. Dvigalo, and Y. Kiryanov, "Volcan Ebeko (Kuril Island): history of eruptic activity and future volcanic danger," Volcanolgy and Seismology, vol. 4, pp. 24-42, 1993.

[18] IA. Menyailov, LP. Nikitina, and VN. Shapar, "Features of chemical and isotopic composition of fumarolic gasses at the 
Ebeko volcano," Journal of Volcanology and Seismology, vol. 4, pp. 21-36, 1988.

[19] E. Kalacheva, Y. Taran, T. Kotenko, K. Hattori, L. Kotenko, and G. Solis-Pichardo, "Volcano-hydrothermal system of Ebeko volcano, Paramushir, Kuril Islands: Geochemistry and solute fluxes of magmatic chlorine and sulfur," Journal of Volcanology and Geothermal Research, vol. 310, pp. 118-131, 2016.

[20] V. A. Baryshev, Y. P. Kolmogorov, G. N. Kulipanov, and A. N. Scrinsky, "X-ray fluorescent method with synchrotron radiation," Journal of Analytical Chemistry, vol. 41, pp. 389-401, 1986 (Russian).

[21] V. Trounova, K. Zolotarev, V. Baryshev, and M. Phedorin, "Analytical possibilities of SRXRF station at VEPP-3 SR source," Nuclear Instruments and Methods in Physics Research Section A: Accelerators, Spectrometers, Detectors and Associated Equipment, vol. 405, no. 2-3, pp. 532-536, 1998.

[22] P. Van Espen, K. Janssens, and J. Nobels, "AXIL-PC, software for the analysis of complex X-ray spectra," Chemometrics and Intelligent Laboratory Systems, vol. 1, no. 1, pp. 109-114, 1986.

[23] S. B. Bortnikova, E. P. Bessonova, and Y. P. Kolmogorov, "Trace Elements in Native Sulphur as the Indicator of Substance Source in Fumarol Incrustation of Volcanic Regions," Journal of Surface Investigation X-ray Synchrotron and Neutron Techniques, vol. 12, pp. 75-78, 2007.

[24] G. P. Avdeiko, O. N. Volynets, A. Y. Antonov, and A. A. Tsvetkov, "Kurile island-arc volcanism: structural and petrological aspects," Tectonophysics, vol. 199, no. 2-4, pp. 271-287, 1991.

[25] I. V. Chaplygin, N. N. Mozgova, I. A. Bryzgalov, and A. V. Mokhov, "Cadmoindite, CdIn2S4, a new mineral from Kudriavy volcano, Iturup isle," Kurily Islands. Zapiski Vserossijskogo Mineralogicheskogo Obshchestva, vol. 133, pp. 21-27, 2004.

[26] A. Garavelli, D. Mitolo, D. Pinto, and F. Vurro, "Lucabindiite, (K,NH4)As4O6 $(\mathrm{Cl}, \mathrm{Br})$, a new fumarole mineral from the " $\mathrm{La}$ Fossa" crater at Vulcano, Aeolian Islands, Italy," American Mineralogist, vol. 98, no. 2-3, pp. 470-477, 2013.

[27] S. V. Churakov, S. I. Tkachenko, M. A. Korzhinskii, R. E. Bocharnikov, and K. I. Shmulovich, "Evolution of composition of high-temperature fumarolic gases from Kudryavy volcano, Iturup, Kuril Islands: The thermodynamic modeling," Geochemistry International, vol. 38, no. 5, pp. 436-451, 2000.

[28] W. H. Zoller, E. S. Gladney, and R. A. Duce, "Atmospheric concentrations and sources of trace metals at the South Pole," Science, vol. 183, no. 4121, pp. 198-200, 1974.

[29] W. H. Zoller, J. R. Parrington, and J. M. Phelan Kotra, "Iridium enrichment in airborne particles from Kilauea volcano: January 1983," Science, vol. 222, no. 4628, pp. 1118-1121, 1983.

[30] E. A. Lepel, K. M. Stefansson, and W. H. Zoller, "The enrichment of volatile elements in the atmosphere by volcanic activity: Augustine volcano 1976," Journal of Geophysical Research: Atmospheres, vol. 83, pp. 6213-6220, 1978.

[31] M. Zelenski, N. Malik, and Y. Taran, "Emissions of trace elements during the 2012-2013 effusive eruption of Tolbachik volcano, Kamchatka: Enrichment factors, partition coefficients and aerosol contribution," Journal of Volcanology and Geothermal Research, vol. 285, pp. 136-149, 2014.

[32] M. Zelenski and S. Bortnikova, "Sublimate speciation at Mutnovsky volcano, Kamchatka," European Journal of Mineralogy, vol. 17, no. 1, pp. 107-118, 2005.

[33] M. Zelenski and Y. Taran, "Volcanic emissions of molecular chlorine," Geochimica et Cosmochimica Acta, vol. 87, pp. 210226, 2012.
[34] F. Africano and A. Bernard, "Acid alteration in the fumarolic environment of Usu volcano, Hokkaido, Japan," Journal of Volcanology and Geothermal Research, vol. 97, no. 1-4, pp. 475495, 2000.

[35] A. Getahun, M. H. Reed, and R. Symonds, "Mount St. Augustine volcano fumarole wall rock alteration: Mineralogy, zoning, composition and numerical models of its formation process," Journal of Volcanology and Geothermal Research, vol. 71, no. 24, pp. 73-107, 1996.

[36] T. J. Casadevall, S. de la Cruz-Reyna, W. I. Rose Jr., S. Bagley, D. L. Finnegan, and W. H. Zoller, "Crater lake and post-eruption hydrothermal activity, El Chichón Volcano, Mexico," Journal of Volcanology and Geothermal Research, vol. 23, no. 1-2, pp. 169191, 1984.

[37] W. F. Giggenbach, "The chemistry of crater lake, Mt. Ruapehu (New Zealand) during and after the, 1971, active period," New Zealand journal of science, vol. 17, pp. 33-45, 1974.

[38] H. Sigurdsson, "Chemistry of the crater lake during the 19711972 soufriére eruption," Journal of Volcanology and Geothermal Research, vol. 2, no. 2, pp. 165-186, 1977.

[39] R. R. Jay, "Determination of polythionic acids," Analytical Chemistry, vol. 25, no. 2, pp. 288-290, 1953.

[40] W. F. Hillebrand, G. E. F. Lundell, H. A. Bright, and J. I. Hoffman, Applied Inorganic Analysis, SE. John Wiley \& Sons, New York, NY, USA, 1953.

[41] B. N. Nikolsky, Spravochnik khimika (Chemist's Handbook), vol. 3, Khimiya Publishing House, Moscow, Russia, 1965.

[42] P. Delmelle and A. Bernard, "Geochemistry, mineralogy, and chemical modeling of the acid crater lake of Kawah Ijen Volcano, Indonesia," Geochimica et Cosmochimica Acta, vol. 58, no. 11, pp. 2445-2460, 1994. 

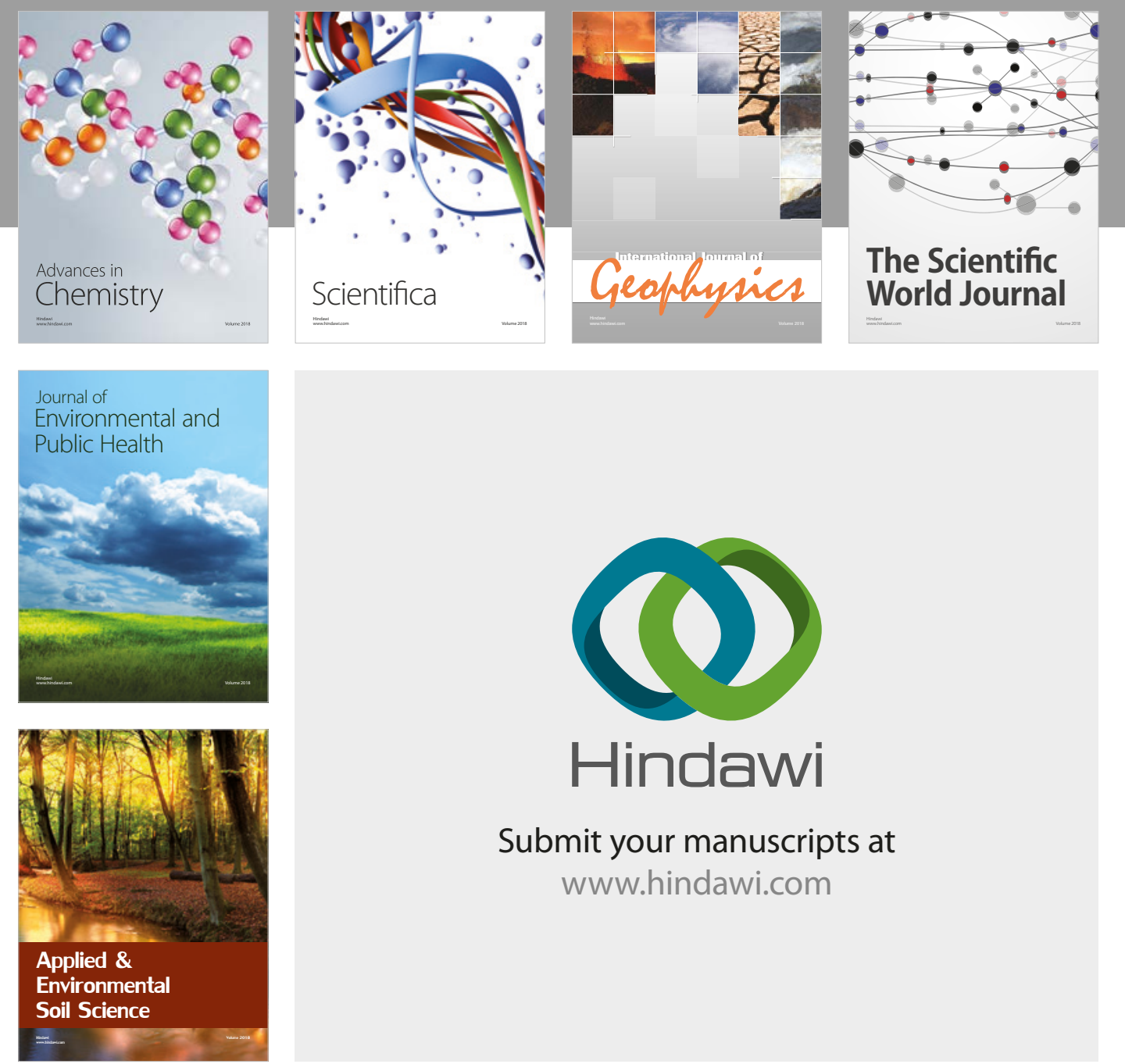

The Scientific

\section{World Journal}
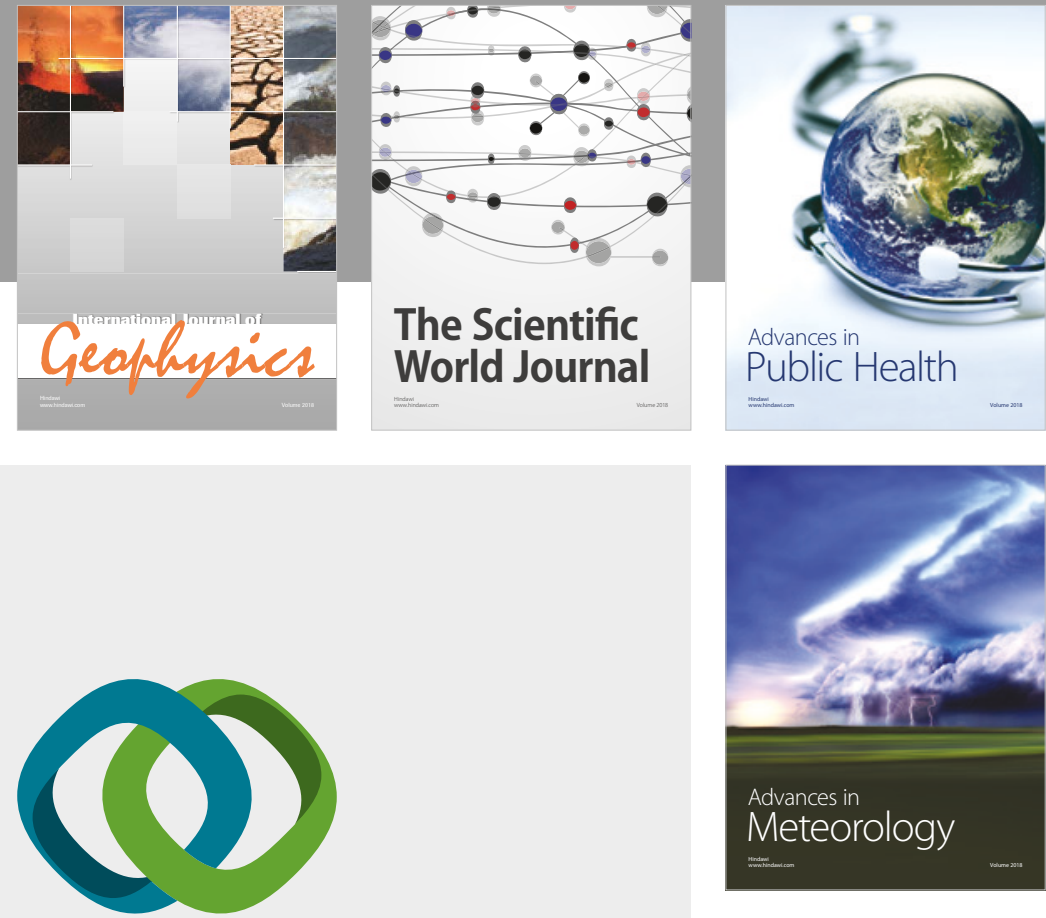

Advan

Public Health

\section{Hindawi}

Submit your manuscripts at

www.hindawi.com
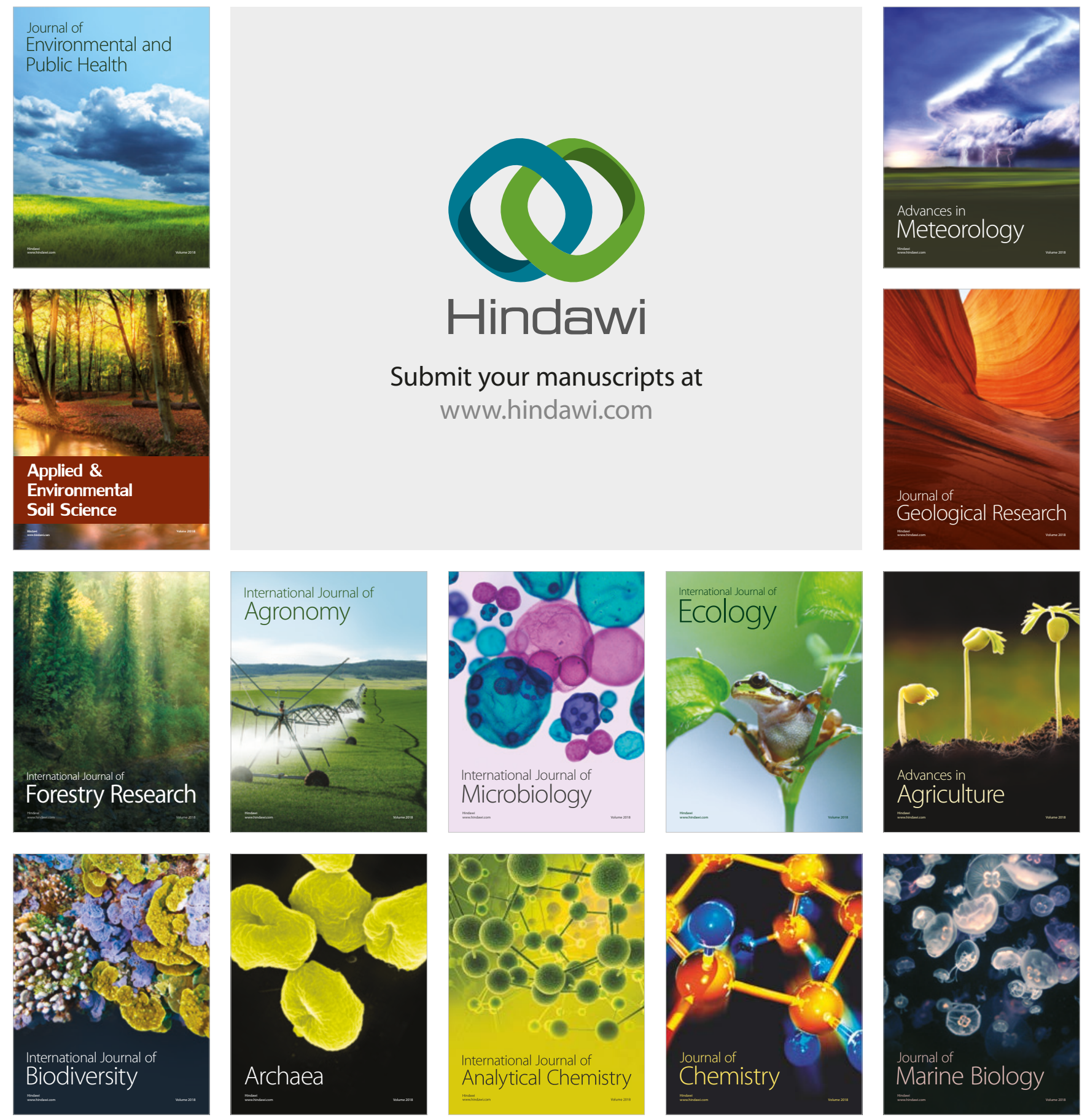